OPEN ACCESS

Edited by:

Paula Rodrigues Oblessuc, New University of Lisbon, Portugal

Reviewed by: Juan Ignacio Vilchez Morillas,

Universidade Nova de

Lisboa, Portugal

Mohammad Khan,

Aligarh Muslim University, India

*Correspondence:

Gustavo Santoyo

gustavo.santoyo@umich.mx

Specialty section:

This article was submitted to

Crop Biology and Sustainability,

a section of the journal

Frontiers in Sustainable Food Systems

Received: 26 February 2021

Accepted: 06 April 2021

Published: 07 May 2021

Citation:

Santoyo G, Gamalero E and Glick BR (2021) Mycorrhizal-Bacterial Amelioration of Plant Abiotic and

Biotic Stress.

Front. Sustain. Food Syst. 5:672881. doi: 10.3389/fsufs.2021.672881

\section{Mycorrhizal-Bacterial Amelioration of Plant Abiotic and Biotic Stress}

\author{
Gustavo Santoyo $^{1 *}$, Elisa Gamalero ${ }^{2}$ and Bernard R. Glick ${ }^{3}$ \\ ${ }^{1}$ Instituto de Investigaciones Químico Biológicas, Universidad Michoacana de San Nicolás de Hidalgo, Morelia, Mexico, \\ ${ }^{2}$ Dipartimento di Scienze e Innovazione Tecnologica, Università del Piemonte Orientale, Alessandria, Italy, ${ }^{3}$ Department of \\ Biology, University of Waterloo, Waterloo, ON, Canada
}

Soil microbiota plays an important role in the sustainable production of the different types of agrosystems. Among the members of the plant microbiota, mycorrhizal fungi (MF) and plant growth-promoting bacteria (PGPB) interact in rhizospheric environments leading to additive and/or synergistic effects on plant growth and heath. In this manuscript, the main mechanisms used by MF and PGPB to facilitate plant growth are reviewed, including the improvement of nutrient uptake, and the reduction of ethylene levels or biocontrol of potential pathogens, under both normal and stressful conditions due to abiotic or biotic factors. Finally, it is necessary to expand both research and field use of bioinoculants based on these components and take advantage of their beneficial interactions with plants to alleviate plant stress and improve plant growth and production to satisfy the demand for food for an ever-increasing human population.

Keywords: rhizosphere, sustainable agriculture, arbuscular mycorrhizal fungi, plant microbiome, plant growthpromoting bacteria

\section{INTRODUCTION}

The world's global population continues to grow alarmingly in the vast majority of countries, leading to various problems in feeding them (Salcedo Gastelum et al., 2020). The latest report on the State of Food Security and Nutrition in the World, published 13 July 2020, clearly shows that "almost 690 million people suffered from hunger in 2019, that is 10 million more than in 2018 and slightly $<60$ million more in 5 years." Moreover, these numbers rise dramatically when considering people unable to maintain a healthy or nutritious diet. Asia, Africa, Latin America, and the Caribbean are the geographical areas characterized by the highest number of undernourished people (381, 250, and 48 million, respectively). Globally, the percentage of undernourished people is estimated to be about $9 \%$ of the world's population. Although this amount has not undergone significant variation over time, there has been a constant upward trend since 2014, indicating that in the last 5 years the problems of inadequate global nutrition has grown proportionally with the increase of the world population (http://www.fao.org/3/ca9692en/online/ca9692en.html\#). Some authors have outlined various intersecting challenges related to world food insecurity ranging from the need for more equitable food distribution, avoiding food waste and ameliorating the impact of climate change (Prosekov and Ivanova, 2018). Another important factor is the production of vegetable crops in a more sustainable way, which involves making a more rational and healthy use of the soil in the long term, avoiding its contamination with the excessive use of chemical fertilizers and pesticides, in addition to the toxic side effects in animal and human health (Mahmood et al., 2016; Khatoon et al., 2020). 
One of the essential factors of a healthy soil are the microorganisms that inhabit it; the soil microbiota is an essential part of biogeochemical cycles, since microorganisms recycle and solubilize essential nutrients for plant growth. Thus, microbial inoculants must be friendly to the environment (Madsen, 2011; Mercado-Blanco et al., 2018). However, much of the world's arable soils do not have optimal cultivation conditions, a problem that presents an additional challenge, i.e., plants growing under conditions of abiotic and biotic stress. Abiotic stresses include drought, soil salinity, flooding, extremes of temperature, and contamination with organic pollutants and heavy metals, while biotic factors include the effects on agricultural production caused by plant pathogens, such as insects, fungi, bacteria, viruses, and nematodes (Santoyo et al., 2017; Gimenez et al., 2018; Gamalero and Glick, 2020). However, the same soil, and in particular, those that inhabit the rhizosphere, may contain beneficial microorganisms, whose associations with plants facilitate plant growth. The rhizosphere may be defined as the part of the soil that is directly influenced by root exudates, which include metabolites, amino acids, or vitamins that can serve as nutrients and stimulate the growth of microbial populations (Olanrewaju et al., 2019; Vives-Peris et al., 2020).

In rhizospheric soil, multiple interactions that are essential to stimulate the growth, health, and development of plants take place among the microorganisms (Trivedi et al., 2020). Two of the main players in this ecosystem are mycorrhizal fungi and plant growth-promoting bacteria (PGPB) (Raklami et al., 2019; Phour et al., 2020). These microorganisms play a key role in sustainable agricultural production, and can enable growers to lessen or avoid the use of chemical fertilizers and pesticides (Molina-Romero et al., 2021). Mycorrhizae (a combination of mycelium of the fungus and the roots of the plant) form networks that capture water and nutrients from the soil, which facilitate the acquisition of the plant. PGPB can also solubilize various nutritional resources or produce antimicrobial compounds that antagonize potential phytopathogens (Bonfante and Anca, 2009; Genre et al., 2020). Interestingly, some bacteria can modulate mycorrhizal symbiosis with the plant. In fact, species of the genus Pseudomonas have been widely studied for their ability to help the mycorrhization process, sometimes being called Mycorrhiza Helper Bacteria (MHB) (Garbaye and Bowen, 1989; Rigamonte et al., 2010; Xing et al., 2018). Thus, the tripartite interaction between mycorrhizae, bacteria and plants can be an excellent strategy for sustainable agricultural production (Glick, 2020; Phour et al., 2020), particularly in regions where abiotic stresses decrease the quality of crops. For example, the salinization of soils in a large part of the world's regions greatly inhibits the growth of plants (Etesami and Beattie, 2017; Etesami and Glick, 2020). Some authors have proposed that up to $20 \%$ of the world's total arable land is affected by this problem, especially in arid and semi-arid regions (Horie et al., 2012; Hanin et al., 2016; Gamalero et al., 2020). In these regions, high temperatures and water scarcity also negatively affect agricultural production, increasing the costs to irrigate crops efficiently (Rodríguez-Flores et al., 2019). In addition, biotic factors, such as the presence of pathogens and pests can destroy crops. Some recent data by Savary et al. (2019) indicate that the annual losses of wheat, rice, maize, potato, and soybean crops worldwide vary between 10 and $40 \%$ of total production, bringing serious economic losses for producers, mainly in highly populated and food-deficit regions. In this sense, the soil microbiota, including mycorrhizae and PGPB, can act to improve the growth and production of plants in the presence of these stresses.

\section{OVERVIEW OF MYCORRHIZAE}

The term mycorrhiza comes from the Greek for "fungus" and "root." In general, mycorrhizal fungi can colonize and form a symbiosis with plant roots externally or internally. Ectomycorrhizae (ECM) are mainly found in associations with trees and shrubs; while endomycorrhizae can be of the arbuscular type (AM), ericoid, and orchid mycorrhizas. AM form associations with a great diversity of plant taxa, while the ericoid mycorrhizae are restricted to the order Ericales and the orchid mycorrhizas to the family Orchidaceae (Genre et al., 2020). For the purposes of this manuscript, only studies related to ECM and $\mathrm{AM}$ are discussed due to their widespread distribution and use in agricultural environments, as well as their known interaction with rhizosphere bacteria.

AM have various propagules, such as spores, hyphae, and rhizomorphs, which are structures that survive in environments such as the rhizosphere. When some ECM spores germinate and form hyphae, these can come into contact with the roots of susceptible plants and form an external mantle, while some others penetrate (mainly) between the cells of the root epidermis, generating a Hartig net. This network increases the contact area between the root cells and the soil, facilitating the uptake and transport of nutrients between both partners (Singh et al., 2016; Genre et al., 2020).

The symbiotic interaction between $\mathrm{AM}$ and plant roots is believed to be $\sim 400$ million years old; moreover, AM inhabit the vast majority of terrestrial plants (Van Der Heijden, 2010). The colonization and signaling processes between mycorrhizae and plants has been more widely studied in AM compared to the interaction between plants and other types of mycorrhizae (Bonfante and Anca, 2009). In general, the stimulation of spore germination in AM is dependent on the plant, since some root exudates can stimulate this process, however, it is not essential. Once the spores germinate, the hyphae must come into contact with the root to begin the colonization process. Volatile organic compounds and strigolactones (chemical compounds produced by plant roots) can initiate and direct the hyphal growth of the fungus, attracting it to enter a symbiotic relationship. Carbon dioxide is one of the volatiles that stimulates the growth of hyphae in AM and is sometimes essential as a nutrient for their growth (Gadkar et al., 2001). In contrast, AM produce Myc factors (short-chain chitin oligomers, sulfated, and non-sulfated lipochitooligosaccharides) to stimulate pre-colonization of the root. Some mutant and transgenic plants with altered synthesis of hormones such as auxins, ethylene, abscisic acid, salicylic acid, strigolactones, jasmonic acid and gibberellic acid, have shown poor, reduced, late or low colonization by AM (Bucher et al., 2014). In order to achieve complete root colonization, the 
arbuscular mycorrhiza is required to develop the hyphopodia or appressoria on the surface of the root, while arbuscular structures are formed within the cortical cells (inter- and intracellular). These arbuscules are hyphae that grow in a branching and spiral way, from which the AM take their name (Figure 1). Root colonization by one AM fungus species does not prevent the establishment of mycorrhizal symbioses with other AM fungal species. In fact, a single plant may be colonized by several different fungal species. As a result, AM fungi can simultaneously interact with different plant hosts and thereby interconnect plants by a so-called common mycorrhizal network (CMN) where both partners can decide on the preferential partners not depending on a single one for the provision of nutrients. Therefore, the CMN connects plants belonging to the same or different species, and represents a long distance transport system for nutrients, water, and stress chemicals in soil, thus affecting survival, and fitness behavior and competitiveness of all of the partners involved in the network (Bücking et al., 2016). To learn more about the molecular and signaling processes involved in the colonization of plants by AM and other mycorrhizal processes, some excellent articles are recommended (Bonfante and Anca, 2009; Bucher et al., 2014; Genre et al., 2020).

\section{MECHANISMS USED BY MYCORRHIZAE TO FACILITATE PLANT GROWTH AND IMPROVE SOIL HEALTH}

Much of the arable soils in the world lack sufficient elemental nutrients (e.g., nitrogen, phosphorus, potassium, zinc), or their bioavailability, to be taken up by plants. In addition, poor agricultural practices such as excessive use of fertilizers, can lead to undesirable ecological side effects such as environmental pollution including the emission of greenhouse gases, downstream contamination, and eutrophication (Parihar et al., 2019). In fact, it is known that $\sim 50 \%$ of the nitrogen fertilizer that is applied onto crops is not taken up by the plants. Therefore, much of this fertilizer is wasted, polluting the ecosystem (Garnett et al., 2009). Below are some of the main mechanisms used by mycorrhizae to optimize the use of soil nutrients and help promote plant growth.

\section{Nutrient Uptake and Improvement of Plant Nutrition}

Numerous studies have shown that one of the main plant growth promotion mechanisms used by mycorrhizae is the facilitation of nutrient uptake such as phosphorus, although evidence suggests that other elements such as nitrogen, sulfur, and zinc are also a fundamental part of this symbiosis (Richardson et al., 2009; Gahan and Schmalenberger, 2014; Hodge and Storer, 2014). In general, mycorrhiza obtains nutrients from the soil and transports them to plant cells in assimilable forms, and in return, the plant supplies the mycorrhiza with photosynthetically fixed carbon (C). It has been suggested that mycorrhizae behave as a carbon sink receiving between 5 and $15 \%$ of the total photosynthesized carbon (Bryla and Eissenstat, 2005; Hodge and Storer, 2014).
Mycorrhization processes may be stimulated in plants growing in nitrogen-limiting soils (Hodge and Storer, 2014). Therefore, given that a large part of agricultural soils lacks sufficient nitrogen to actively promote plant growth, establishing a symbiosis with mycorrhiza is essential for plant growth and production. The external hyphae of mycorrhizae can take up ammonium $\left(\mathrm{NH}^{4+}\right)$, mobile nitrate $\mathrm{NO}^{3-}$ or nitrogenous amino acids such as arginine (Govindarajulu et al., 2005). During the interaction with some other prokaryotic organisms (e.g., ammonia oxidizing bacteria and archaea), mycorrhizae may be a fundamental part of the functioning of an ecosystem and the $\mathrm{N}$ cycle, by carrying out the conversion of $\mathrm{NH}^{4+}$ to $\mathrm{NO}^{3-}$ during nitrification, and mineralizing organic $\mathrm{N}$ to inorganic forms. Genera such as Rhizobium, Mesorhizobium, and Sinorhizobium interact with legumes, can fix atmospheric $\mathrm{N}$ and convert it to ammonia. Other nitrogen-fixing bacteria, such as Azospirillum, can fix nitrogen in association with non-leguminous plants and in plant organs other than nodules (Hernaández-Esquivel et al., 2020). Various studies have shown that some AM may have a positive impact on the rhizosphere microbiome and be capable of altering the amount of carbon and nitrogen available to other organisms (Hodge and Storer, 2014).

$\mathrm{P}$ is also typically a limiting element for plant growth. This nutrient is typically found as orthophosphate anions (predominantly $\mathrm{HPO}_{4}{ }^{2-}$ and $\mathrm{H}_{2} \mathrm{PO}_{4}{ }^{1-}$ ) from the soil, although in most soils the concentration of orthophosphate in solution is low (Richardson et al., 2009). In one study, it was shown that when a root-hairless mutant (brb) of barley (Hordeum vulgare cv. Pallas) was grown in low $\mathrm{P}$ contents, mycorrhization significantly increased the uptake of this nutrient in this plant. The authors concluded that the mycorrhizal effect substituted for the presence of root hairs during $\mathrm{P}$ uptake, and that it was essential in promoting plant growth (Jakobsen et al., 2005). Besides that, it has been well-demonstrated that root colonization by mycorrhizal fungi is strongly suppressed by the presence of high soil concentration of phosphate (Baylis, 1967; Mosse, 1973). However, the level of inhibition can be different according to the fungal partner and the plant species (Johnson, 1993; Van Geel et al., 2016).

\section{Soil Nutrient Loss Reduction}

Mycorrhizae are widely known for their role in improving plant nutrition. However, some mechanisms such as facilitating the avoidance of the loss of nutrients from the soil are poorly understood. Mycorrhizae, and in particular AM, play a relevant role in this process. Some processes by which AM reduce and/or prevent nutrient loss from the soil include the production of glomalin (He et al., 2020). The protein glomalin (a glycoprotein) significantly improves soil aggregation, thus preventing the loss of nutrients from soil by leaching and denitrification. Also, glomalin can chelate inorganic phosphorus and retain it for subsequent use by mycorrhiza and plants (Vlček and Pohanka, 2020). AM can also participate in the regulation of nitrification processes, increase water intake, as well as the regulatory systems that involve the loss of nutrients in the form of gases, mainly nitrogen. In this regard, species such as Glomus intraradices, Rhizophagus irregularis, Funneliformis mosseae, Claroideoglomus 


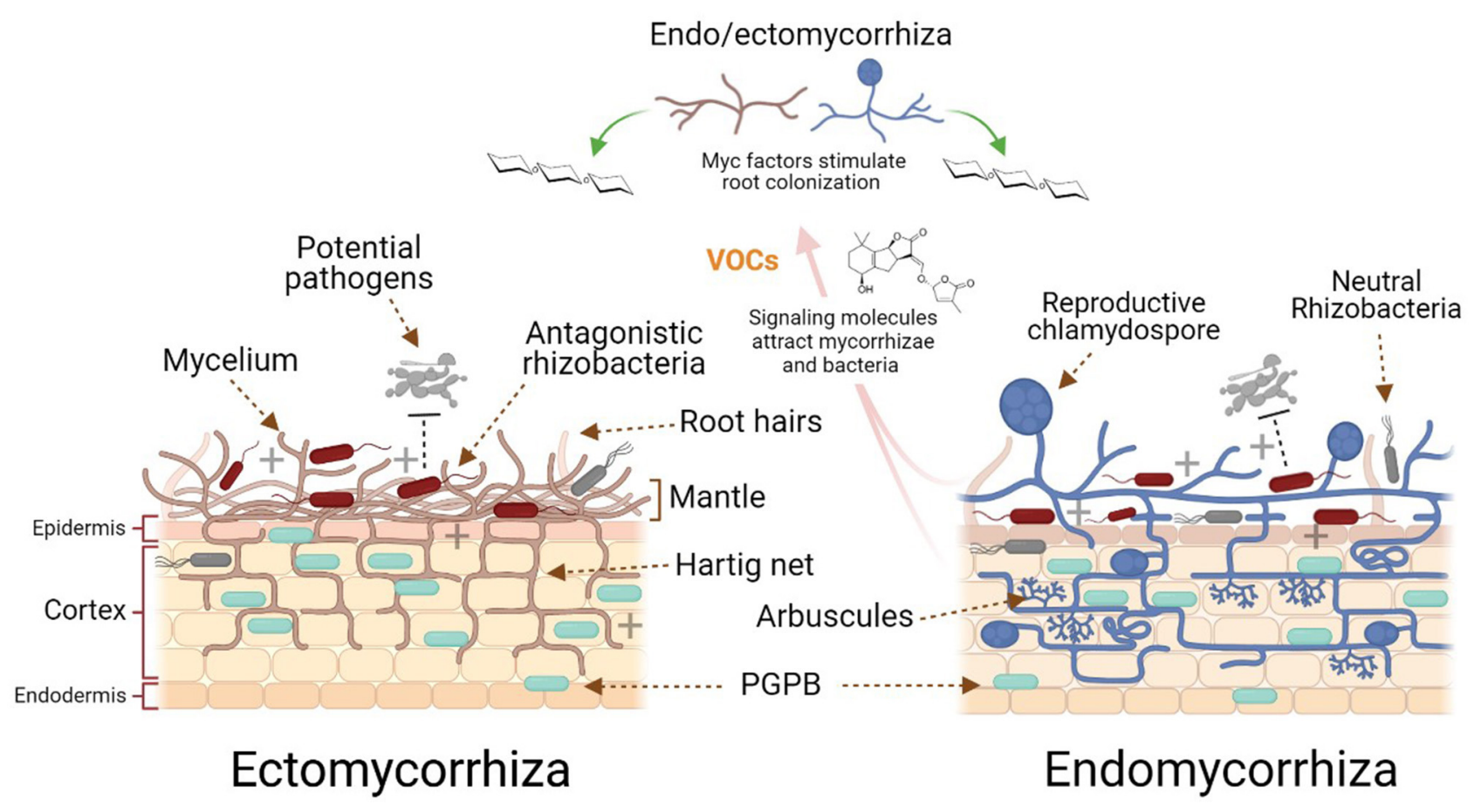

FIGURE 1 | Schematic illustration of the endo- and ectomycorrhizal general differences and interactions in the rhizosphere. Plant strigolactones and volatile compounds attract beneficial ecto- and endomycorrhiza and plant growth-promoting bacteria (PGPB). Ectomycorrhizae form an external mantle, while endomycorrhizae mainly penetrate between the cells of the root epidermis to generate a Hartig net mycorrhizae and auxin-like compounds produced by the mycorrhizae to stimulate pre-colonization of the plant roots.

claroideum have been shown to be efficient at preventing the loss of nutrients from the soil, and thereby indirectly, stimulate plant growth (Van Der Heijden, 2010; Bender et al., 2015; Bowles et al., 2018).

\section{Soil Aggregation}

As previously mentioned, AM produce and excrete glomalins that can improve soil aggregation, avoiding the loss of nutrients from the soil by processes such as leaching. Glomalins and glomalin-related soil proteins (GRSP) are highly effective and give added value to bioinoculation products based on AM. These proteins exhibit physical and chemical properties that make them suitable for use in improving the structure of soils, particularly those affected by erosion processes. Glomalins are difficult to destroy, show poor water solubility, and in general, they are very stable proteins that protect the surface of soil aggregates ( $\mathrm{He}$ et al., 2020; Vlček and Pohanka, 2020). In a recent study, GRSPs produced by three different species of AM (Diversispora epigaea, Paraglomus occultum, and Rhizoglomus intraradices) were used to inoculate trifoliate orange (Citrus trifoliata) and shown to contribute significantly to the retention of soil organic carbon (He et al., 2020). In addition to the retention of nutrients, a better soil structure can also help to retain more water, avoiding generating additional stress in crop systems.

\section{Soil Bioremediation}

Agricultural soils can be affected by different pollutants which negatively affect the health of the soil and therefore, plant growth and production. The action of the rhizosphere microbiota, including fungi and bacteria, can ameliorate some aspects of this stress. For example, glomalin-related soil proteins (GRSP) produced by species like Glomus intraradices, Glomus versiforme, and Acaulospora laevis can function as bioindicators of pollutants in the soil and other aquatic environments. This is due to the ability of these GRSPs to interact and bind to contaminating metals in the soil (Wang et al., 2020). Other studies have shown that GRSPs, as well as various mycorrhizal fungi that produce them including the genera Ilyonectria, Chaetomium, Gibberella, Paraphoma, Schizothecium, Pseudorobillarda, Tetracladium, Ganoderma, Cadophora, Exophiala, Knufia, Mycoleptodiscus, Cyphellophora, Fusicolla, Devriesia, Didymella, Plenodomus, Pyrenochaetopsis, Symbiotaphrina, Phallus, Coprinellus, Plectosphaerella, Septoriella, and Hypholoma can function in contaminated environments and be potential bioremediators; particularly, in contaminated soils with polycyclic aromatic hydrocarbons (Gałazka et al., 2020).

Some mycorrhizal fungi have naturally evolved the ability to degrade/transform polluting compounds generated by human actions (Aguilar et al., 2011). Likewise, some soil bacteria are also highly effective in bioremediation processes, often acting synergistically with AM to form consortia that allow efficient cleaning of contaminated soils. This is important because agricultural soils are frequently surrounded and affected by industrial activities (Maas et al., 2010; Kim et al., 2020). 


\section{Priming Plant Defense}

Mycorrhizae are not particularly known to be direct antagonists of plant pathogens, nor do they contain the same antimicrobial arsenals as some other organisms (Vigo et al., 2000; Ravnskov et al., 2020; Santoyo et al., 2021). Nevertheless (1) AM symbiosis can reduce some of the damage to plants that is caused by soil-borne plant pathogens or parasites, (2) the enhancement of plant resistance/tolerance differs according to the AM species, (3) the level of plant protection changes with the phytopathogenic organism species, and (4) plant protection is modulated by a variety of soil and environmental conditions. AM can promote plant protection against phytopathogens through various indirect mechanisms. For example, mycorrhizae are capable of stimulating the defense mechanisms of plants, such as the production of phenolic compounds and an increase in plant pathogenesis-related proteins (PR) (Shaul et al., 1999; Song et al., 2015). Other indirect mechanisms include the competition with pathogens for nutrients and spaces on the plant as well as the improvement of the general health of the plant. Anatomical and morphological changes in the root system such as lignification and topology of the root system, can make the plant less susceptible to root infection and more efficient in nutrient uptake (Berta et al., 1993, 2002). Another aspect that should be taken into account is the stimulation of the plant's defenses through changes in the rhizospheric microbiome. AM can stimulate the production of root exudates which, in turn, modulate the bacterial community (Offre et al., 2007) and possibly stimulate the proliferation of pathogen-antagonistic bacterial populations in the rhizosphere (Hodge and Storer, 2014). In turn, some bacteria can promote the growth and colonization of mycorrhizal fungi (Garbaye, 1994).

\section{OVERVIEW OF PLANT GROWTH-PROMOTING BACTERIA (PGPB)}

Plants are surrounded (below- and above-ground) by a plethora of microorganisms, including a large number of bacterial species. Those known as plant growth-promoting bacteria (PGPB) refers to bacteria that can associate with and significantly influence plant growth (Orozco-Mosqueda et al., 2018, 2020). The external areas from where they can stimulate plant growth include the phyllosphere, the surface of the aerial parts of the plant including the flowers, seeds, stems and leaves (Liu et al., 2020). Another widely studied microsystem is the rhizosphere, where a large part of the interactions with mycorrhizae take place. The rhizosphere is the part of the soil that is directly influenced by the root exudates (Trivedi et al., 2020). This ecosystem, which can vary in size and depends on the root system of each plant, can extend from a few centimeters to several meters, as is the case for the rhizosphere of trees and shrubs that have a broad root system. The rhizosphere contains an extensive reservoir of PGPB, and a great diversity of plant beneficial species have been isolated from this region of the soil (Kuzyakov and Razavi, 2019).

The bacterial diversity of the plant rhizosphere is dynamic and can vary depending on several biotic and abiotic factors. For example, in a study of the maize rhizosphere, analyzed through different stages of growth, it was found that in general the dominant genera were Massilia, Burkholderia, Ralstonia, Dyella, Chitinophaga, and Sphingobium. While the genera Massilia, Flavobacterium, Arenimonas, and Ohtaekwangia were relatively abundant at early growth stages, populations of the genera Burkholderia, Ralstonia, Dyella, Chitinophaga, Sphingobium, Bradyrhizobium, and Variovorax were dominant in the later stages of plant growth (Li et al., 2014).

Abiotic factors such as $\mathrm{pH}$, the soil water content, salinity, aggregate size, and soil texture, as well as the presence of heavy metals and the soil temperature, also greatly influence its composition and the bacterial population structure associated with plants (Vos et al., 2013; Santoyo et al., 2017). Moreover, under stress conditions, plants can recruit a beneficial microbiome that allows them to better interact and resist stressful conditions. For example, drought-sensitive plants (Capsicum annuum L.) cultivated in a traditional Egyptian farm, recruited bacteria with plant growth-promoting capacities from the rhizosphere and helped them to ameliorate drought stress conditions by increasing the photosynthetic capacity of the plant as well as the total biomass (Marasco et al., 2012).

PGPB and plants also interact in the plant endosphere. PGPB that colonize internal plant tissues, without causing damage to the plant, may be defined as plant growth-promoting bacterial endophytes (Santoyo et al., 2016). Bacterial endophytes utilize essentially the same mechanisms to promote plant growth as other PGPB, however, genomic comparison studies with rhizosphere bacteria indicate that they have a few unique genetic features (Ali et al., 2014). For example, endophytic bacteria contain mechanisms that allow them to colonize the endophytic environment, such as the production of cell wall degrading enzymes (cellulase, glucanase, and chitinase), production of carbohydrate active enzymes (CAZymes) and flagellar and secretion systems (e.g., T6SSs). Genomic studies of endophytic bacterial species have confirmed these genetic requirements, and examples include Azospirillum, Arthrobacter, Bacillus, Burkholderia, Devosia, Dyadobacter, Enterobacter, Gluconacetobacter, Leifsonia, Methylobacterium, Microbacterium, Micrococcus, Paenibacillus, Pantoomonas, Phylhanelobacterus, Pantobacterium, Phylhanelobacterium, Rhodanelon, Rheinheimera, Sphingomonas, Stenotrophomonas, and Pedobacter (Orozco-Mosqueda and Santoyo, 2021). Genomic analyses of these endophytic species indicate that together with rhizospheric or phyllospheric bacteria, they present a common core that allows them to stimulate plant growth through both direct and indirect mechanisms (Ali et al., 2014; Orozco-Mosqueda and Santoyo, 2021). Some of these bacterial plant promotion mechanisms are discussed below.

\section{MECHANISMS USED BY PGPB TO FACILITATE PLANT GROWTH}

The direct and indirect mechanisms used by PGPB have been previously reviewed, in both the absence (Glick, 2012; Santoyo et al., 2016; Khatoon et al., 2020; Phour et al., 2020) and presence of different abiotic and biotic stresses (Glick, 2004; Mayak et al., 
2004; Palaniyandi et al., 2014; Ullah et al., 2019; Morales-Cedeño et al., 2021). However, here we review some of them briefly.

\section{Direct Mechanisms}

Direct mechanisms of plant growth promotion include the facilitation of resource and nutrient acquisition such as the solubilization and mineralization of phosphates (Glick, 2012), a mechanism also employed by mycorrhizae to facilitate plant growth and nutrition. PGPB may also produce siderophores that can solubilize and bind iron from the rhizosphere.

Rhizobia, as well as some other PGPB can fix atmospheric $\mathrm{N}_{2}$, convert it into ammonia and provide it to plants. The uptake of bacterially-fixed nitrogen not only facilitates plant growth, but can also increase the nutritional value of crop plants (Peralta et al., 2004). Another direct mechanism of plant growth stimulation involves the production of hormones that play an important role in the growth and development of the plant including indoleacetic acid, cytokinin, gibberellin, abscisic acid, salicylic acid, brassinosteroids, and jasmonate (Munné-Bosch and Müller, 2013). Some PGPB species can produce more than one hormone with the impact of hormone(s) dependent on the endogenous concentration of that hormone in the plant. In addition to producing phytohormones, many PGPB possess the enzyme ACC deaminase which can lower plant ethylene levels (Glick, 2004). The crosstalk between hormones produced by PGPB and those by the plant can regulate various growth stages, either in the presence or absence of different types of biotic or abiotic stress (Santoyo et al., 2017; Kumar et al., 2020; Wu et al., 2020).

\section{Indirect Mechanisms}

PGPBs can stimulate plant growth indirectly, that is, they can restrict the functioning of potential pathogens and/or stimulate the plant's immune system. The indirect mechanisms of PGPB are therefore of great interest in their application in the field, since they avoid the use of chemical biocides (Adesemoye and Kloepper, 2009; Adesemoye et al., 2009; Khatoon et al., 2020). The fact that a PGPB exhibits both direct and indirect mechanisms of plant growth promotion can be an advantage for being part of a more complete bioinoculant (HernándezLeón et al., 2015), and, if a bacterial strain with both types of mechanisms interacts beneficially with other rhizospheric microorganisms, such as mycorrhizae, the beneficial effect on the plant can be synergistic. Hence, there is considerable interest in deciphering the molecular mechanisms of microbial interactions.

Some PGPB produce a series of lytic enzymes that act by lysing the cell walls of pathogenic fungi and oomycetes. Fungal and oomycetes cell walls are dynamic structures that are essential for cell morphogenesis, viability, and pathogenesis (Bowman and Free, 2006). Lytic enzymes produced by PGPB include glucanase, chitinase, cellulase, protease, and lipase activity. The fungal cell walls contain beta-D-glucans, cellulose, protein, and chitin; while oomycetes contain mostly quintin, beta-D-glucans and alpha-D-mannans, and cellulose in minor amounts (Inglis and Kawchuk, 2002). Oomycetes are able to form hyphae, and the vast majority of organisms in the class Oomycetes are plant pathogens, including obligate biotrophs like the downy mildews
Bremia lactucae, Hyaloperonospora parasitica, and Plasmopara viticola; white rusts like Albugo spp.; hemibiotrophs like Phytophthora infestans and Phytophthora sojae; and necrotrophs like Phytophthora cinnamomi, Pythium spp. (Hardham, 2007; Dodds et al., 2009). Some other well-known pathogenic fungi include genera like Botrytis spp., Rhizoctonia spp., Fusarium spp., and Verticillium spp. All of these pathogens cause serious damage to crops so that inhibiting the development of the diseases that they cause through the application of PGPB is imperative for the sustainability of agricultural ecosystems (Morales-Cedeño et al., 2021). Lytic enzymes produced by PGPB can also induce damage to the eggshells of plant parasitic nematodes, which are composed of a protein matrix and chitin. This activity can be of great interest when developing a new biofertilizer/biopesticide since nematodes cause $\sim 12.3 \%$ of the losses per year suffered globally by and especially in developing countries (Gamalero and Glick, 2020).

Major indirect mechanisms include the synthesis of antibiotic compounds, whether they are diffusible (e.g., 2, 4-diacetylphloroglucinol, phenazines, pyoluteorin, pyrrolnitrin, etc.) or volatile (e.g., dimethyl disulfide, dimethylhexadecylamine, hydrogen cyanide, etc.) (Glick, 2012). In addition, indirect antagonism mechanisms include the colonization of spaces on the plant that might otherwise be occupied by phytopathogens and the synthesis of chelating compounds such as siderophores, which can act as antagonists under iron-limiting conditions, due to the fact that they make iron less available to the harmful microbiota (Kloepper et al., 1980; Dowling and O'Gara, 1994). Some of the compounds and enzymes mentioned above (e.g., pyoverdine, chitin or $\beta$-glucans) can also act as triggers of induced systemic resistance (ISR) in plants. ISR induction by these compounds (and other compounds including jasmonates, salicylic acid, lipolysaccharides, etc.) has been demonstrated on Arabidopsis, tomato, bell pepper, muskmelon, watermelon, sugar beet, tobacco, cucumber, among many other plants during both greenhouse and field trials (Choudhary and Johri, 2009; Sarma et al., 2015).

When plants are stressed by various biotic factors, they synthesize excess amounts of ethylene. This stress hormone can cause senescence, chlorosis, and abscission in plants, exacerbating the damaging effects caused by the pathogens (Dubois et al., 2018; Etesami and Glick, 2020). Therefore, lowering ethylene levels in stressed plants can lead to improved growth, and some PGPB have the capacity to do this through the production of the enzyme 1-aminocyclopropane-1-carboxylate (ACC) deaminase. ACC deaminase cleaves ACC, a precursor of ethylene synthesis, into $\alpha$-ketobutyrate and ammonia (OrozcoMosqueda et al., 2020). Reducing the levels of the ethylene precursor, ACC, decreases ethylene production, freeing the plant of such a stress signal. Multiple studies have demonstrated the efficacy of the ACC deaminase enzyme produced by PGPB to protect plants from attack by pathogens, including fungi and oomycetes. Similarly, it has been observed that ACC deaminase (and some other compounds such as trehalose) can also decrease ethylene levels in plants stressed by various abiotic factors, such as flooding, salinity, and heavy metal contamination in 
soils or drought (Cheng et al., 2007; Brígido et al., 2019; Del Carmen Orozco-Mosqueda et al., 2019; Paço et al., 2020). Figure 2 provides a schematic representation of the individual and synergistic mechanisms exerted by mycorrhizae and PGPB.

\section{INTERACTION BETWEEN MYCORRHIZAE AND PLANT GROWTH-PROMOTING BACTERIA}

\section{Interactions in the Absence of Stress}

While the literature regarding AM/PGPB interactions is quite large, a search using the words ectomycorrhizal fungi and PGPB as keywords reveals only 11 papers in the scientific literature. Similarly, when searching ectomycorrhizal fungi and MHB only 33 papers are shown since the year 1996. This indicates that the amount of available information regarding the interactions between ectomycorrhizal fungi and plant beneficial bacteria is limited and is mainly focused on the positive effects of the bacterial strains on the development of the fungal partner (and, indirectly, on plant growth). The trend of the published papers is easily understandable if considering that the ectomycorrrhizal symbiosis involves a large number of fungal species $(10,000$ species belonging to Basidiomycotina, Ascomycotina, and some Zygomycotina), but a very limited amount of plant species including most coniferous trees, larch, birch, beech, oak, and eucalypts. Some of these fungi have a strict host specificity and only associate with one tree species, for example, Suillus grevillei with Larix decidua (Churchland and Grayston, 2014). On the other hand, AM, belonging to the subphylum Glomeromycotina (Spatafora et al., 2016), are able to establish an obligate symbiosis with $\sim 65 \%$ of all known land plant species, most of which have an economical or agricultural importance.

The first report of bacterial-ectomycorrhizae interactions was by Garbaye and Bowen (1989) who demonstrated that bacterial strains isolated from the mantle of the Pinus radiataRhizopogon luteolus ectomycorrhizas favor the establishment of ectomycorrhizal symbiosis. In 1994, Garbaye defined this specific group of microorganisms as mycorrhization-helper bacteria (MHB) referring to bacteria able to enhance mycorrhizal colonization by 1.2-17.5 times through the stimulation of the pre-symbiotic growth of the fungus, as well as the development of the mycelium during the symbiotic stages. Since then, a number of MHB belonging to Gram-negative Proteobacteria, Grampositive Firmicutes, and Actinobacteria have been described both for ecto- and arbuscular mycorrhizae (Frey-Klett et al., 2007).

Bacteria living in association with ectomycorrhizal fungi can affect the aromatic component of the fungus. In fact, bacteria living on Tuber borchii, a cultivated truffle species, impacts the development of the truffle aroma. A fruiting body of T. borchii, especially when at full maturity and stored at room temperature, emits volatiles such as 3-methylthiophene and 3-methyl-4,5dihydrothiophene, which are main components of the truffle aroma (Splivallo et al., 2015). The $\alpha$ - and $\beta$-Proteobacteria that are dominant in the microbiome of $T$. borchii were able to carry out the chemical reactions previously described. Moreover, treating fruiting bodies with antibacterial molecules fully suppressed the production of thiophene volatiles, while fungicides had no inhibitory effects, demonstrating the bacterial involvement in these chemical transformations (Splivallo et al., 2015).

The degree of intimacy between bacteria and the ectomycorrhizal fungi can be very different: bacterial isolates can live as planktonic cells in the mycorrhizosphere, form specialized biofilms around the mycorrhiza or occupy the internal space of the hyphae (Frey-Klett et al., 2011). As an example, when cultivated in sterilized bioreactors, the ectomycorrhizal fungus Laccaria bicolor S238N, used as a commercial biofertilizer for mycorrhization of Douglas fir, produced cultures that were found to be "contaminated" by bacteria. Microscopic images obtained showed the sporadic occurrence of bacterial cells, identified as Paenibacillus spp., inside the hyphae (Bertaux et al., 2003). Unfortunately, the precise role of this, and other bacterial fungal endophytes, remains to be elaborated.

Bacteria living inside AM cells or propagules were first described by Mosse (1970). About 12 years later, others bacterial cells were found in the spores of Glomus mosseae (now Funnelliformis mosseae), Gigaspora margarita and Gigaspora heterogama (MacDonald et al., 1982). Thus, the occurrence of endobacteria inside AM cytoplasms has been well-documented.

Based on electron microscopy images it has been possible to distinguish two morphotypes of bacterial cells. One morphotype is represented by rod-shaped, gram negative cells typically associated with AM belonging to Gigasporaceae. Initially, they were considered to be unculturable Burkholderia and further classified as Candidatus Glomeribacter gigasporarum (Bianciotto et al., 2004). These bacterial cells were found with a high density (about 19,000 bacteria per spore in all fungal compartments except arbuscules) and were vertically transmitted during fungal sporulation (Bianciotto et al., 2003). Bacterial genes involved in phosphate transport ( $p s t)$ and host cell colonization $(v a c B)$ were detected suggesting an involvement of bacterial cells in the provision of nutrients (Ruiz-Lozano and Bonfante, 1999, 2000). Subsequently, using a fungal line cured of these endobacteria it has been finally demonstrated that the bacteria confer an ecologically relevant fitness to the fungal host, especially at the presymbiotic stage (Lumini et al., 2007).

The second morphotype includes coccoid bacterial cells living inside AM spores and hyphae colonizing plant roots grown in field conditions that have been collectively called "bacteriumlike organism" (BLO) (MacDonald et al., 1982). Based on the results obtained, the question arises: are the BLOs in the fungal cytoplasm the result of an occasional re-infection by freeliving bacteria, or is this their distinctive feature? This question remained unsolved until 2010 when Naumann et al. (2010) analyzed the spores of 16 species of AM belonging to highly divergent Glomeromycota lineages from 28 spore cultures from four different continents by FISH, electron microscopy and phylogenetic analysis. The occurrence of BLO were observed in 19 of the 28 spore cultures and were associated with 11 of the 16 AM tested species. Microscopic observation revealed that BLO were coated by a thick Gram-positive cell wall and embedded in the fungal cytoplasm. However, sequencing of the bacterial cells showed that their DNA clustered in a monophyletic clade not related to any other bacterial taxa, but forming a subclade within 


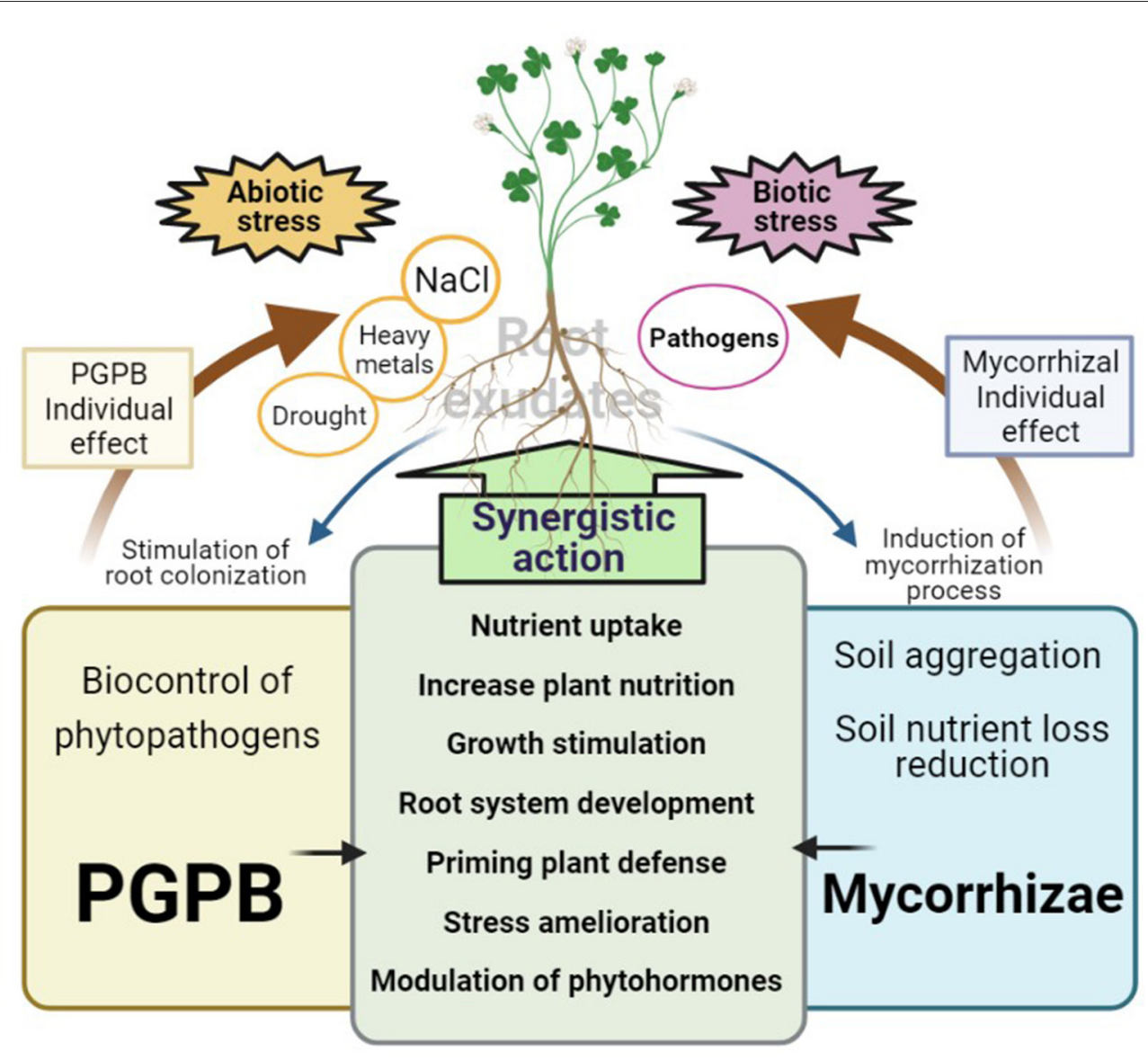

FIGURE 2 | Description of the individual and synergistic mechanisms exerted by mycorrhizae and PGPB. Mycorrhizae and PGPB contain very few individual mechanisms to interact with their plant host. For example, PGPB are mostly known as biocontrol agents of phytopathogens, while mycorrhizae have excellent activities to improve diverse soil properties; however, most of these shared beneficial activities between mycorrhizae and PGPB may be acting synergically to stimulate plant growth (directly or indirectly) either in the absence or presence of abiotic and biotic stress. Plant root exudates also stimulate the colonization of PGPB, as well as the mycorrhization process, accelerating the tripartite interaction (Plant-Mychorrizae-PGPB).

the Mollicutes, a class of the Tenericutes phylum whose members are typically wall-less. Based on this new classification, they are now referred as Mollicutes/mycoplasma-related endobacteria or MRE. Although it has been speculated that they can modulate the fungal host fitness, MRE function remain to be investigated. More recently, in order to recognize this unique lineage of endosymbionts, the new species "Candidatus Moeniiplasma glomeromycotorum" has been proposed (Naito et al., 2017).

Besides bacteria living as endophytes inside mycorrhizal fungi, bacteria living in the rhizosphere or mycorrhizosphere and behaving as PGPB can have a direct impact on plants that is equivalent to that of the fungus. The resulting effect can be expressed as plant growth and development, biocontrol or tolerance against phytopathogenic organisms and improvement of nutritional value.

The first publications on AM/PGPB interactions reported heterogeneous and often inconsistent plant responses to combined inoculation in open field conditions (Meyer and Linderman, 1986; Germida and Walley, 1996) highlighting the occurrence of a high degree of specificity between plant, bacterial species and AM isolates. While effects on plant growth and yield following inoculation with AM/PGPB are widely reported (Gamalero et al., 2009; Fadiji and Babalola, 2020; Moreira et al., 2020), the impact of these microorganisms on root development has been less explored.

Co-inoculation of Pseudomonas fluorescens 92rk and the AM Glomus mosseae BEG12 (now Funnelliformis mosseae) on tomato plants yielded a synergistic effect on root fresh weight and phosphorus uptake. Looking at root morphogenesis, the treatment with the bacterial strain and the AM fungus significantly increased the number of tips, the root length, area, volume, and branching compared to plants inoculated with only one of the microorganisms (Gamalero et al., 2004). All of these modifications make the root system more efficient in nutrient uptake and soil exploration.

The mechanisms by which bacteria stimulate AM colonization are still poorly understood, but certain bacterial activities, such as the production of metabolites increasing root cell permeability 
and hormone synthesis, are expected to be involved. Among the plant hormones, ethylene has a controversial role on mycorrhizal symbiosis establishment. While it has been indicated that ethylene can significantly inhibit mycorrhizal colonization, especially under P deficient conditions (Zsögön et al., 2008), low levels of ethylene favors mycorrhizal symbiosis establishment in plants cultivated at high phosphorus level (Torres de los Santos et al., 2016).

PGPB that produce the enzyme ACC deaminase are able to modulate plant ethylene concentrations. For example, the effect of co-inoculation of the ACC deaminase-producing strain Pseudomonas sp. UW4 (Duan et al., 2013) or its mutant, impaired in ACC deaminase synthesis, with the AM fungus Gigaspora rosea on cucumber plants was reported (Gamalero et al., 2008). Consistent with the observation made on pea plants inoculated with rhizobia able to synthesize ACC deaminase (Ma et al., 2003), strain UW4, but not the mutant, increased AM colonization and arbuscule abundance of G. rosea. Moreover, P. sp. UW4 inoculated with the AM induced synergistic effects on plant biomass, total root length and total leaf projected area. In addition, the photosynthetic efficiency was improved in plants inoculated with the two microorganisms.

Although positive interaction between AM fungi and PGPB have been frequently found in plants growing under controlled conditions, knowledge of the impact of these microorganisms on plant growth and nutrition, in open fields is scant. It has recently been demonstrated that inoculation of a bacterial consortium containing two rhizobia strains (Ensifer meliloti RhOF4 and E. meliloti RhOF155), two PGPB (Acinetobacter sp. BS17 and Rahnella aquatilis PGP27), and an AM mixture (Glomus sp., Sclerocystis sp., and Acaulospora sp.) on wheat and faba bean plants grown in open field conditions induced synergistic effects (Raklami et al., 2019). Plant treatment with these microorganisms improved the growth parameters (shoot and root dry weights) of both plant species. Enhancement of shoot and root dry weights, and the number of leaves in faba bean plants reached 130, 200, and $78 \%$ of the control values, respectively. Similarly, wheat shoot and root dry weights and number of leaves were enhanced by 293 , 258 , and $87 \%$, respectively. Inoculation with the PGPB, AM and Rhizobia consortium improved the yield of the two plant species as observed from the number and weight of bean pods $\left(270 \times 10^{4}\right.$ $\mathrm{ha}^{-1}$ and $\left.30737.5 \mathrm{~kg} \cdot \mathrm{ha}^{-1}\right)$ and wheat spikes $\left(440 \times 10^{4} \mathrm{ha}^{-1}\right.$ and $10560 \mathrm{~kg} \cdot \mathrm{ha}^{-1}$ ).

Plant inoculation with AM fungi and PGPB seems to satisfy two objectives of modern agriculture; combination of these microorganisms not only increases plant biomass, but also positively affects the nutritional value of seeds and fruits (Duhamel and Vandenkoornhuyse, 2013; Bona et al., 2018).

\section{Interactions in the Absence of Stress Under Field Conditions}

Different studies have been performed both under controlled and in open field conditions. For example, inoculation with a mixed mycorrhizal inoculum and/or two PGPB (Pseudomonas fluorescens Pf4 and Pseudomonas sp. 5Vm1K) increased the yield and modulated the soluble sugar, organic acid, and vitamin (ascorbic and folic acid) contents in strawberry plants cultivated under reduced fertilization. Co-inoculation with AM fungi and each of the two PGPB led to an increased flowering rate and level of fruit production. Fruits with larger size, and higher concentrations of sugars and vitamins were produced by AM/PGPB inoculated plants compared to those produced by uninoculated ones. The results obtained in this work highlight the role of microorganisms living in the rhizosphere affecting fruit crop quality when plants are grown with a reduced amount of chemicals, suggesting a possible application for sustainable agriculture (Bona et al., 2017).

Similar results have been obtained in maize plants with experiments performed in the field. Maize plants, inoculated with AM fungi and PGPB, harvested after 7 months of growth in open-field conditions showed increased plant growth and yield. The main effect of AM was on the aerial plant parts $(+16.6 \%$ increased shoot dry weight compared to untreated plants), while Pseudomonas fluorescens Pf4 positively affected root growth (+68\% increase compared to uninoculated plants). Both spikes and grains produced by inoculated plants were larger than those produced by non-inoculated plants. Interestingly, the two microorganisms differentially modulated the nutritional components: the PGPB enhanced grain starch content, especially the digestible fraction, whereas the AM fungi increased the amount of protein, especially the zein, content. Maize inoculation with both the PGPB and AM fungi resulted in additive effects on grain nutrient composition (Berta et al., 2014).

Tomato plants of two different cultivars (Bona et al., 2017, 2018) inoculated with AM fungi and two PGPB (Pseudomonas sp. $19 \mathrm{Fv1T}$ or P. fluorescens C7) and grown in open field conditions with low fertilization levels showed enhanced flower and fruit production, as well as increased tomato size. According to the tomato cultivar, sugar and vitamins concentration was increased by the selected microorganisms; the most significant effect of AM fungi inoculation was the enhancement of citric acid content in fruits, while bacteria positively modulated sugar production and the resulting sweetness of the tomatoes. Although the two bacterial strains did not affect root colonization, the glucose and fructose amount was highest in the combined treatment $(+13 \%$ increased glucose and $+19 \%$ increased fructose). This is important for sweetness perception when tomatoes are intended for industrial use. Moreover, all of the combinations of microorganisms led to a higher malic acid content, while coinoculation of AM/PGPB increased the $\beta$-carotene concentration in the fruits. These results clearly demonstrated that the combined use of AM and PGPB allowed for a 30\% decrease in the application of chemical fertilizers without any risk of yield reduction leading to a significant benefit to the economy, environment and human health.

The interactions between rhizobia and AM fungi in terms of facilitating plant yield have been reported in a number of studies in the literature (Requena et al., 1997; Mortimer et al., 2008; Raklami et al., 2019). However, there is scant information regarding the impact of rhizobia and AM fungi coinoculation on the nutritional value of legume seeds. Recently, Massa et al. (2020) demonstrated that Phaseolus vulgaris plants inoculated with AM and R. leguminosarum PhVyNOD3 
and grown in open field conditions produced seeds with a different nutritional profile compared to uninoculated plants. Although the yield and fiber content did not vary among the treatments, only $R$. leguminosarum PhVyNOD3 enhanced the starch concentration in seeds. Moreover, the seed protein amount was higher when the seeds were from rhizobium-inoculated plants either with or without AM compared to uninoculated control plants. In addition, the mineral content of $\mathrm{Mg}, \mathrm{K}$, and $\mathrm{Zn}$ were higher in seeds produced by mycorrhizal plants and $\mathrm{Mn}$ was more abundant in seeds from plants inoculated only with the rhizobia strain. Interestingly, the number of nodules did not change in AM inoculated plants; however, the mycorrhizal colonization was higher in mycorrhizal plants inoculated with the rhizobia strain than in plants treated only with AM. Besides demonstrating that the use of rhizobia and AM fungi as biostimulants allows for the reduction of chemical fertilization, without any reduction of the yield, this work showed that appropriate biofertilizers can improve the nutritional quality of a crop (Table 1).

\section{Interactions in the Presence of Abiotic Stress}

PGPB and AM fungi are widely known for their beneficial activities when co-inoculated into various agricultural crops. As previously mentioned, this type of consortium can improve soil fertility, improve nutrient acquisition, and stimulate plant growth and production (Berta et al., 2014; Raklami et al., 2019; Massa et al., 2020). PGPB and AM not only act in the absence of some type of stress but can also improve plant growth under abiotic stress. For example, the presence of strains of Brevibacillus spp. (from lead-contaminated soil) co-inoculated with AM fungi was a relevant factor in the mycorrhization process. In addition, such co-inoculation improved the development of Trifolium pratense L. plants under adverse environmental conditions, like lead contamination (Vivas et al., 2003). This suggests that there is a close interaction between bacteria and AMF, as there is a stimulation of the beneficial activities of AM by bacterial strains.

Similarly, this type of interaction has been seen between strains of Sphingomonas sp., Pseudomonas sp., Massilia sp., and Methylobacterium sp. and an AM fungus (Phylum Glomeromycota) in a soil that was highly contaminated with aliphatic and aromatic petroleum hydrocarbons. The presence of the aforementioned genera was reported when sampling within intra-radical propagules, which were collected from the roots of plants (Solidago rugosa) grown in sediments contaminated with petroleum hydrocarbons. The propagules collected showed surprisingly high bacterial richness associated with AM within the roots of plants. The authors suggested that the bacteria associated with mycorrhizae could be acting in synergy in processes such as mycorrhization and phytoremediation (Iffis et al., 2014).

Recently, the synergy between PGPB and AM in interaction with plants growing in contaminated agricultural soils, as well as phytoremediation activities, has been recently reported (Guarino et al., 2020). The phytoremediation of soil contaminated with petroleum hydrocarbons was evaluated in two plant species, Oloptum miliaceum and Pennisetum setaceum. Interestingly, this hydrocarbon breakdown process was carried out by rhizobacteria with good emulsification activity, in addition to the fact that these enzymatic activities were stimulated by AM in the rhizosphere. These results suggested that choosing bacteria with good production of lipolysaccharides, ACC deaminase and able to synthesize siderophores, would be an effective strategy to attack recalcitrant molecules, such as petroleum hydrocarbons (Liu et al., 2015).

In this sense, a microbial consortium composed of a plant growth-promoting rhizobacterium (Variovorax paradoxus 5C-2), a nitrogen-fixing rhizobium strain (Rhizobium leguminosarum by Viciae RCAM1066) and an AM fungus (Glomus sp. 1Fo), managed to stimulate accumulation and tolerance to cadmium in cadmium-resistant pea plants (Pisum sativum L.) (Belimov et al., 2020). Importantly, the stimulation of cadmium tolerance was comparable to the agricultural crop Indian mustard (Brassica juncea L.). Species belonging to the Brassicaceae family are widely known for their excellent abilities to mediate soils contaminated with heavy metals and metalloids, including arsenic, lead, copper, zinc, and cadmium (Salido et al., 2003; Turan and Esringü, 2007; Belimov et al., 2020).

Another type of stress that plants often face is the limitation of water or drought, which can greatly limit their growth and production (Sharma and Dubey, 2005). Some regions of the world are classified as arid or semi-arid areas, where plants cannot grow at the high temperatures that evaporate the available water and that generate constant stress due to the scarcity of water. Mycorrhizae and PGPB can alleviate some of this stress in plants (Gamalero et al., 2009; Bona et al., 2017; Emmanuel and Babalola, 2020), as demonstrated by Pereira et al. (2016) in their study where they observed that endophytic native Bacillus strains co-inoculated with strains of arbuscular mycorrhizal fungus, increase drought tolerance in Lavandula dentata plants by stimulating oxidative metabolism. Additionally, microorganisms increased plant growth and nutrition under these stress conditions. It should be noted that the bacteria, as well as the AM, were pre-evaluated and showed tolerance to drought, an important requirement when selecting microorganisms as inoculants under these conditions.

A mixture of AM and PGPB to contain water stress in walnut plants (cv. Chandler) was evaluated by (Behrooz et al., 2019). The authors used the bacteria Azotobacter chroococcum and Azospirillium lipofrum together with the AM Glomus mosseae and G. etunicatum, as well as respective single inoculations. The results showed that the co-inoculation of the microbial consortium, compared to the separate inoculations of each microorganism, alleviated the negative effects (reduced growth and leaf nutrient content such as $\mathrm{N}, \mathrm{P}$, and $\mathrm{Zn}$ ) of drought stress on walnut seedlings. Therefore, the simultaneous application of $\mathrm{AM}$ and PGPB increased the production of some metabolites involved in water stress tolerance, such as total phenolic content, proline level, total soluble sugar, and starch content. Similarly, the inoculated plants improved their peroxidase enzyme activity.

Another study that has shown that mixed inoculations of AM (Claroideoglomus etunicatum) and PGPB (Micrococcus yunnanensis) can improve and stimulate the growth of hervaceous plants sensitive to drought (Dracocephalum 
TABLE 1 | Examples of pioneering and recent works reporting interactions between mycorrhizae and bacteria.

\begin{tabular}{|c|c|c|c|c|}
\hline Bacteria & Mycorrhizae & Crop/plant species & $\begin{array}{l}\text { Type of interaction or } \\
\text { effect on plant }\end{array}$ & References \\
\hline $\begin{array}{l}\text { Actinomycetes, fluorescent } \\
\text { bacteria }\end{array}$ & Rhizopogon luteolus & Pinus radiata & $\begin{array}{l}\text { Stimulation of } \\
\text { ectomycorrhizal infection }\end{array}$ & Garbaye and Bowen, 1989 \\
\hline $\begin{array}{l}\text { Pseudomonas cepacia R55, } \\
\text { P. aeruginosa R80, P. } \\
\text { fluorescens R92, P. putida } \\
\text { R104 }\end{array}$ & Arbuscular Mycorrhizal Fungi (AMF) & $\begin{array}{l}\text { Wheat (Triticum aestivum L. } \\
\text { cv. Laura) }\end{array}$ & $\begin{array}{l}\text { Alteration of rooting patterns } \\
\text { and mycorrhizal colonization }\end{array}$ & Germida and Walley, 1996 \\
\hline Pseudomonas putida & $\begin{array}{l}\text { Vesicular Arbuscolar-Mycorrhizal } \\
\text { Fungi }\end{array}$ & $\begin{array}{l}\text { Clover/Trifolium } \\
\text { subterraneum L. }\end{array}$ & $\begin{array}{l}\text { Increment of Fe, } \mathrm{Cu}, \mathrm{Al}, \mathrm{Zn} \text {, } \\
\mathrm{Co} \text { and Ni elements in shoot }\end{array}$ & Meyer and Linderman, 1986 \\
\hline $\begin{array}{l}\text { Pseudomonas fluorescens } \\
\text { 92rk and P190r }\end{array}$ & $\begin{array}{l}\text { Glomus mosseae BEG12 (now } \\
\text { Funnelliformis mosseae) }\end{array}$ & $\begin{array}{l}\text { Tomato/Lycopersicon } \\
\text { esculentum Mill. }\end{array}$ & $\begin{array}{l}\text { Synergistic effect on root } \\
\text { fresh weight and } \\
\text { phosphorus uptake }\end{array}$ & Gamalero et al., 2004 \\
\hline $\begin{array}{l}\text { Pseudomonas sp. UW4 wild } \\
\text { type and AcdS- mutant }\end{array}$ & Gigaspora rosea & $\begin{array}{l}\text { Cucumber/Cucumis } \\
\text { sativum L. }\end{array}$ & $\begin{array}{l}\text { Stimulation of plant growth } \\
\text { by the AcdS }+ \text { strain }\end{array}$ & Gamalero et al., 2008 \\
\hline$\alpha$ - and $\beta$-Proteobacteria & Tuber borchii & None & Emission of truffle aroma & Splivallo et al., 2015 \\
\hline Pseudomonas fluorescens C7 & $\begin{array}{l}\text { Rhizophagus intraradices, } R . \\
\text { aggregatus, Septoglomus viscosum, } \\
\text { Claroideoglomus etunicatum and } C . \\
\text { claroideum }\end{array}$ & $\begin{array}{l}\text { Tomato/Lycopersicon } \\
\text { esculentum Mill. }\end{array}$ & $\begin{array}{l}\text { Improved tomato quality } \\
\text { and reduced fertilization }\end{array}$ & Bona et al., 2018 \\
\hline $\begin{array}{l}\text { Pseudomonas fluorescens } \\
\text { Pf4 }\end{array}$ & $\begin{array}{l}\text { Rhizophagus intraradices, Glomus } \\
\text { aggregatum, Glomus viscosum, } \\
\text { Glomus etunicatum, and Glomus } \\
\text { claroideum }\end{array}$ & Maize/Zea mays L. & $\begin{array}{l}\text { Improved plant } \\
\text { development and grain } \\
\text { quality production }\end{array}$ & Berta et al., 2014 \\
\hline $\begin{array}{l}\text { Pseudomonas sp. 19Fv1T } \\
\text { and P. fluorescens C7 }\end{array}$ & $\begin{array}{l}\text { Rhizophagus intraradices, Glomus } \\
\text { aggregatum, Glomus viscosum, } \\
\text { Claroideoglomus etunicatum and } \\
\text { Claroideoglomus claroideum }\end{array}$ & $\begin{array}{l}\text { Tomato/Solanum } \\
\text { lycopersicum L. }\end{array}$ & $\begin{array}{l}\text { Improved yield, quality and } \\
\text { nutritional value of tomato }\end{array}$ & Bona et al., 2017 \\
\hline $\begin{array}{l}\text { Ensifer meliloti RhOF4, E. } \\
\text { meliloti RhOF155, } \\
\text { Acinetobacter sp. BS17 and } \\
\text { Rahnella aquatilis PGP27 }\end{array}$ & $\begin{array}{l}\text { Glomus sp., Sclerocystis sp., and } \\
\text { Acaulospora sp. }\end{array}$ & $\begin{array}{l}\text { Faba bean/Vicia faba L. and } \\
\text { wheat/Triticum durum L. }\end{array}$ & $\begin{array}{l}\text { Improvement on crop } \\
\text { nutrition and production, as } \\
\text { well as better soil fertility }\end{array}$ & Raklami et al., 2019 \\
\hline Fifteen Rhizobial strains & $\begin{array}{l}\text { Rhizophagus intraradices, } R . \\
\text { aggregatus, Septoglomus viscosum, } \\
\text { Claroideoglomus etunicatum and C. } \\
\text { claroideum }\end{array}$ & $\begin{array}{l}\text { Common bean/Phaseolus } \\
\text { vulgaris cv. Billò }\end{array}$ & $\begin{array}{l}\text { Positive effect on seed } \\
\text { quality and reduced } \\
\text { fertilization }\end{array}$ & Massa et al., 2020 \\
\hline
\end{tabular}

moldavica) was carried out by Ghanbarzadeh et al. (2020). Moldavian balm is a herb with multiple uses in the pharmaceutical, cosmetic, food, and flavoring industries (Amini et al., 2020). In this study, the authors evaluated three irrigation regimes (40, 70 and $100 \%$ field capacity), observing various negative effects in non-inoculated plants. On the other hand, plants inoculated with a mixture of Claroideoglomus etunicatum and Micrococcus yunnanensis improved their growth under stress conditions, presenting stimulation of their antioxidant enzymatic activities, such as ascorbate peroxidase, guaiacol peroxidase, and superoxide dismutase.

Salt stress has serious negative consequences on agricultural production. The effects of soil salinity have similar effects to those of drought in plants, and therefore, the responses are also similar (Forni et al., 2017). For example, both drought and high salt cause the stimulation of the biosynthesis of compatible osmoprotectants and the activation of antioxidant enzymes. However, saline stress, unlike water stress, increases the concentration of salts $\left(\mathrm{Na}^{+}, \mathrm{Cl}^{-}\right)$causing an imbalance of these ions, resulting in alterations in gene expression and cellular metabolism (Hu and Schmidhalter, 2005). Several studies on inoculations with AM and PGPB separately have shown improvements in alleviating the toxic effects caused by excess salt in plants (Porcel et al., 2012; Ilangumaran and Smith, 2017; Orozco-Mosqueda et al., 2020). However, there is evidence that the simultaneous inoculation of both groups of microorganisms can be synergistic (Gamalero et al., 2010; Lee et al., 2015; Santoyo et al., 2021).

A recent study showed that the co-inoculation of bacteria of the genus Pseudomonas and Pantoea, together with the AM Rhizoglomus irregulare, can have a positive effect on the nutrient content of corn plants (Zea mays) including nitrogen and magnesium, in addition to reducing the ions such as $\mathrm{Na}^{+}$ that hyper-accumulate in saline soils. The authors concluded that mixed inocula ( $R$. irregularis, $P$. reactans EDP28, and $P$. alli ZS 3-6) is an effective means of relieving salt stress in corn plants (Moreira et al., 2020).

Other mixtures of AM and PGPB have also shown good results in corn plants (Lee et al., 2015; Krishnamoorthy et al., 2016). Glomus etunicatum and Methylobacterium oryzae CBMB20 
strains, when co-inoculated in soil, significantly increased dry biomass, AM root colonization, and nutrient accumulation in maize plants under salt stress (Lee et al., 2015), while $R$. intraradices and Massilia sp. RK4 exhibited better results on AM root colonization and nutrient accumulation in plants compared to single inoculation with the fungus (Krishnamoorthy et al., 2016). In both studies, the microorganism mixtures lead to the improved growth of corn under conditions of salinity stress.

Some mechanisms of plant growth promotion in bacteria, such as ACC deaminase activity, have been evaluated in their interaction with AM such as Gigaspora rosea BEG9. For this, ACC deaminase-producing strain Pseudomonas sp. UW4 (AcdS ${ }^{+}$) and its mutant unable to produce ACC deaminase $\left(\mathrm{AcdS}^{-}\right)$were evaluated in their interaction with the AM Gigaspora rosea BEG9. The two abovementioned strains were, separately, co-inoculated with BEG9 in cucumber plants under salt stress conditions. The results showed that the ACC deaminase activity was important when interacting with the fungus, with a synergistic effect being observed between the PGPB and the AM when stimulating the growth and photosynthetic capacity of the plants, compared to plants that were co-inoculated with the mutant strain, lacking ACC activity (Gamalero et al., 2010) (Table 2).

\section{Interactions in the Presence of Biotic Stress}

The mycorrhizal symbiosis has multiple beneficial impacts on plant stress tolerance, including in adverse environmental situations where there is scarcity of water or a high level of salt or toxic metals. However, mycorrhizal fungi also exhibit benefits during interaction with plants challenged with pathogens (biotic stress) through the action of several proposed indirect mechanisms, such as competitive exclusion and providing a protective mantle in roots (Hooker et al., 1994). In addition, mycorrhizae induce the proliferation of antagonistic bacteria associated with plants, as well as inducing the production of antimicrobial compounds in mycorrhized plants (Edwards et al., 1998). As previously mentioned, mycorrhizae also stimulate the defense mechanisms of plants such as producing phenolic compounds and increasing the synthesis of plant pathogenesisrelated proteins (PR) (Shaul et al., 1999; Al-Askar and Rashad, 2010; Song et al., 2015).

Some authors have emphasized that the symbiosis between endo and ectomycorrhiza with plants may only suppress the action of pathogens (i.e., fungi or nematodes) under certain conditions (Vigo et al., 2000; Ravnskov et al., 2002; Whipps, 2004; Wehner et al., 2010). For example, some studies suggest that the root architecture of plants, whether mycorrhized or not, is an important factor for susceptibility to attack by pathogens (Sikes, 2010). On the other hand, negative interactions between the soil microbiota and arbuscular mycorrhizae have also been proposed by some research groups (Ravnskov et al., 2002; Svenningsen et al., 2018). It has also been postulated that rhizosphere pathogens have adapted very well to parasitize mycorrhizal hosts and to be able to colonize plants causing disease (Graham, 2001). However, positive cooperation between AM fungi and PGPB in suppressing phytopathogenic organisms or eliciting plant defenses has been widely reported both for aerial and soil borne pathogens, as well as for bacteria, fungi, and parasitic nematodes (Akhtar et al., 2011; D’Amelio et al., 2011; Freire Cruz and de Oliveira Soares, 2014; Imperiali et al., 2017; Nepomuceno et al., 2019; Alaux et al., 2020; Ravnskov et al., 2020).

Thus, D'Amelio et al. (2011) described the effects of the co-inoculation of Pseudomonas putida S1Pf1Rif and F. mosseae BEG12 on Chrysanthemum carinatum plants infected by chrysanthemum yellows phytoplasma (CY), also focusing on phytoplasma replication and viability. The AM/PGPB combination led to a lower number of infected plants after exposure to leafhopper vectors, delayed symptom expression, and modifications of root morphology especially of root tip number and branching degree. Phytoplasma infected plants showed reduced growth compared to uninfected ones, but inoculation with AM/PGPB enhanced plant biomass and rescued the inhibition of plant development caused by the phytoplasma. Inoculation with $P$. putida S1Pf1Rif and F. mosseae BEG12 did not affect phytoplasma replication and viability. However, phytoplasma cells observed in the phloem elements were often degenerated and senescent.

Tomato plants infested with the root-knot nematode Meloidogyne incognita and inoculated with two PGPB (Pseudomonas jessenii R62 and Pseudomonas synxantha R81) and an AM strain (Rhizophagus irregularis) showed increased plant growth and reduced nematode infection. In addition, AM/PGPB treated plants exhibited significant increases of phenolics (28\%) and defensive enzymes i.e., peroxidase (PO; 1.26-fold), polyphenyloxidase (PPO; 1.35-fold), and superoxide dismutase (SOD; 1.09-fold) involved in development of resistance to the nematode (Sharma and Sharma, 2017). Unfortunately, this work shows an effect of AM/PGPB in disease suppression without identifying the mechanisms responsible for this effect. However, one possible mechanism is the elicitation of mycorrhiza-induced resistance (MIR) by AM against biotic stresses. In a model proposed by Cameron et al. (2013) it has been suggested that AM and PGPB can cooperate in a complex sequence of interactions to trigger MIR. According to this model, mycorrhizal development is favored during presymbiotic growth by the release of strigolactones by the root system of the host plant (Akiyama et al., 2005). During the first stages of the symbiotic phase, a localized response mediated by a transitory rise of salicylic acid occurs; this, in turn, activates the salicylic acid dependent plant defense pathways. However, a compromise with the fungus, aiming to establish a symbiosis, must be found so that the AM try to inhibit these pathways probably reprogrammes plant local defenses, through the activation of the synthesis of abscisic acid (Ton et al., 2009). As a result, the composition of the root exudates changes and the defenses that depend on abscisic acid are activated. Then, when the mycorrhizal symbiosis is established and stable, bacteria living in the mycorrhizosphere can elicit plant defense pathways dependent on jasmonic acid and ethylene (Van der Ent et al., 2009).

In another recent study (Nepomuceno et al., 2019), an inoculant based on Glomus mosseae and G. fasciculatum was evaluated, reduced the application of chemical fertilizers by $50-100 \%$, and together with other growth-promoting bacteria 
TABLE 2 | Example of works reporting the beneficial interaction between Mycorrhizae and plant growth-promoting bacteria under abiotic and biotic stress conditions.

\begin{tabular}{|c|c|c|c|c|}
\hline Bacteria & Mycorrhizae & Crop/plant species & Type of stress/benefit & References \\
\hline Brevibacillus spp. & Mixture of AM fungi & $\begin{array}{l}\text { Red clover/Trifolium } \\
\text { pratense L. }\end{array}$ & $\begin{array}{l}\text { Stimulation of plant growth under } \\
\text { heavy-metal contamination }(\mathrm{Pb})\end{array}$ & Vivas et al., 2003 \\
\hline $\begin{array}{l}\text { Sphingomonas sp., } \\
\text { Pseudomonas sp., Massilia sp., } \\
\text { and Methylobacterium sp. }\end{array}$ & Glomeromycota & Solidago rugosa Mill. & $\begin{array}{l}\text { Potential stimulation of plant growth } \\
\text { in a contaminated soil with aliphatic } \\
\text { and aromatic petroleum } \\
\text { hydrocarbons }\end{array}$ & Iffis et al., 2014 \\
\hline $\begin{array}{l}\text { Rhizobium leguminosarum bv. } \\
\text { Viciae RCAM1066 and } \\
\text { Variovorax paradoxus 5C-2 }\end{array}$ & Glomus sp. 1Fo & Pea/Pisum sativum L. & $\begin{array}{l}\text { Increased accumulation and } \\
\text { tolerance to cadmium }\end{array}$ & Belimov et al., 2020 \\
\hline $\begin{array}{l}\text { Azotobacter chroococcum and } \\
\text { Azospirillium lipofrum }\end{array}$ & $\begin{array}{l}\text { Glomus mosseae and G. } \\
\text { etunicatum }\end{array}$ & $\begin{array}{l}\text { Walnut plants/Juglans regia } \\
\text { cv. Chandler }\end{array}$ & $\begin{array}{l}\text { Reduction of negative effects of } \\
\text { drought stress on plants }\end{array}$ & Behrooz et al., 2019 \\
\hline Micrococcus yunnanensis & $\begin{array}{l}\text { Claroideoglomus } \\
\text { etunicatum }\end{array}$ & Dracocephalum moldavica & $\begin{array}{l}\text { Plant growth promotion under } \\
\text { drought stress and stimulation of } \\
\text { antioxidant enzymatic activities }\end{array}$ & Ghanbarzadeh et al., 2020 \\
\hline $\begin{array}{l}\text { Methylobacterium oryzae } \\
\text { CBMB20 }\end{array}$ & Glomus etunicatum & Maize/Zea mays L. & $\begin{array}{l}\text { Increased plant biomass, AMF root } \\
\text { colonization, and nutrient uptake }\end{array}$ & Lee et al., 2015 \\
\hline Massilia sp. RK4 & R. intraradices & Maize/Zea mays L. & $\begin{array}{l}\text { MF root colonization and nutrient } \\
\text { accumulation in plants }\end{array}$ & Krishnamoorthy et al., 2016 \\
\hline $\begin{array}{l}\text { Pseudomonas putida UW4 } \\
\text { (AcdS }^{+} \text {) and a mutant unable to } \\
\text { produce the ACC deaminase } \\
\text { enzyme }\end{array}$ & Gigaspora rosea BEG9 & $\begin{array}{l}\text { Cucumber/Cucumis sativus } \\
\mathrm{L} \text {. }\end{array}$ & $\begin{array}{l}\text { Amelioration of plant growth under } \\
\text { salt stress }\end{array}$ & Gamalero et al., 2010 \\
\hline $\begin{array}{l}\text { Pseudomonas reactans EDP28, } \\
\text { and Pantoea alli ZS 3-6 }\end{array}$ & Rhizoglomus irregulare & Maize/Zea mays L. & $\begin{array}{l}\text { Synergic effects to promote plant } \\
\text { growth under salt stress }\end{array}$ & Moreira et al., 2020 \\
\hline Pseudomonas putida S1Pf1Rif & F. mosseae BEG12 & Chrysanthemum carinatum & $\begin{array}{l}\text { Increased plant tolerance against } \\
\text { chrysanthemum yellows } \\
\text { phytoplasma ("Candidatus } \\
\text { Phytoplasma asteris") }\end{array}$ & D'Amelio et al., 2011 \\
\hline $\begin{array}{l}\text { Pseudomonas jessenii R62 and } \\
\text { Pseudomonas synxantha R81 }\end{array}$ & Rhizophagus irregularis & $\begin{array}{l}\text { Tomato/Solanum } \\
\text { lycopersicum cv. PT-3 }\end{array}$ & $\begin{array}{l}\text { Protection against the root-knot } \\
\text { nematode Meloidogyne incognita }\end{array}$ & Sharma and Sharma, 2017 \\
\hline $\begin{array}{l}\text { Alcaligenes sp., Lichtheimia sp., } \\
\text { and Brevibacterium sp. }\end{array}$ & $\begin{array}{l}\text { Glomus mosseae and } G . \\
\text { fasciculatum }\end{array}$ & $\begin{array}{l}\text { Onion/Allium cepa L. var. } \\
\text { Red Creole }\end{array}$ & $\begin{array}{l}\text { Protection against the pathogen } \\
\text { Sclerotium rolfsii }\end{array}$ & Nepomuceno et al., 2019 \\
\hline Paenibacillus rhizospherae & Gigaspora margarita & $\begin{array}{l}\text { Apricot/Prunus mume and } \\
\text { other fruit seedlings }\end{array}$ & $\begin{array}{l}\text { Tolerance to the soilborne pathogen } \\
\text { Rosellinia necatrix infection }\end{array}$ & $\begin{array}{l}\text { Freire Cruz and de Oliveira } \\
\text { Soares, } 2014\end{array}$ \\
\hline $\begin{array}{l}\text { P. protegens CHAO-Rif and } P \text {. } \\
\text { chlororaphis PCL1391 }\end{array}$ & Rhizoglomus irregulare & Wheat/Triticum aestivum & $\begin{array}{l}\text { Prevalence and persistence of mix } \\
\text { inoculum on wheat rhizosphere }\end{array}$ & Imperiali et al., 2017 \\
\hline
\end{tabular}

plant, such as Alcaligenes sp., Lichtheimia sp., and Brevibacterium sp., protected onion crops against the attack of the soil borne pathogen Sclerotium rolfsii. Interestingly, the results showed that neither the inoculation with mycorrhizae nor bacteria separately provided protection to the onion plants, and that it required the participation of both microorganisms to reduce the incidence of the disease from 20 to $40 \%$. The above suggests a synergy between mycorrhizae and bacteria to control pathogens such as Sclerotium rolfsii.

Freire Cruz and de Oliveira Soares (2014) also reported that the use of the arbuscular mycorrhizal fungus, Gigaspora margarita, and the PGPB Paenibacillus rhizospherae to alleviate white root rot (caused by the root fungal pathogen Rosellinia necatrix Bearl ex Prill) in Japanese apricot (Prunus mume) and three other fruit seedlings (grape, fig, and apple). The application of the AM + PGPB mixture showed beneficial results in apricot, fig, and apple seedlings, by reducing the severity caused by the pathogen, but not in apple. Therefore, although the positive results depended on the plant species analyzed, the authors suggest that the combination of AM + PGPB may have a synergistic impact on certain species of fruit seedlings and that its presence in soils could be used as an indicator of fruit tree tolerance to the soilborne pathogen Rosellinia necatrix.

Few studies explore the effect of the application of microorganisms in the field, where environmental conditions and biotic factors can significantly influence the results. However, this type of study is necessary to understand such interactions and how "control" them and predict stochastic situations. Thus, Imperiali et al. (2017) evaluated the inoculation of wheat seeds with PGPB ( $P$. protegens CHA0-Rif and P. chlororaphis PCL1391), AM (Rhizoglomus irregulare), and four entomopathogenic nematodes (Heterorhabditis megidis, Heterorhabditis bacteriphora, Steinernema carpocapsae, and Steinernema feltiae), and evaluated their effect over a growing season. While all three organisms survived and adapted to field conditions, the best positive effect was observed following the 
treatment of a wheat crop under biotic stress caused by Oscinella frit. This insect is considered to be a major agricultural pest, boring into the shoots of oats, wheat, maize, barley, and grasses (Imperiali et al., 2017).

In a 2-year field experiment, the combination of PGPB (Pseudomonas monteilii) and AM (Glomus fasciculatum) had a protective effect on Coleus forskohlii, a medicinal plant that is the source of forskolin, against root rot and wilt caused by the fungal pathogens Ralstonia solanacearum and Fusarium chlamydosporum. Besides increasing plant height (+38\%), tuber yield $(+103 \%)$ and forskolin content $(+25 \%)$, plant inoculation with $\mathrm{AM} / \mathrm{PGPB}$ reduced wilt incidence $(-68 \%)$ and root rot $(-63 \%)$ in C. forskohlii compared to uninoculated control plants. Moreover, the bacterial strain behaves as a MHB on $G$. fasciculatum increasing its colonization efficiency (Singh et al., 2013).

Previous works show that the interactions between both groups of microorganisms, AM and PGPB, as well as their individual contributions (Miransari, 2011), are required in inoculants to stimulate the health and plant growth of agricultural crops, protecting them from potential pathogens (Table 2).

\section{REFERENCES}

Adesemoye, A. O., and Kloepper, J. W. (2009). Plant-microbes interactions in enhanced fertilizer-use efficiency. Appl. Microbiol. Biotechnol. 85, 1-12. doi: 10.1007/s00253-009-2196-0

Adesemoye, A. O., Torbert, H. A., and Kloepper, J. W. (2009). Plant growth-promoting rhizobacteria allow reduced application rates of chemical fertilizers. Microb. Ecol. 58, 921-929. doi: 10.1007/s00248-0099531-y

Aguilar, R., Hormazábal, C., Gaete, H., and Neaman, A. (2011). Spatial distribution of copper, organic matter and $\mathrm{pH}$ in agricultural soils affected by mining activities. J. Soil Sci. Plant Nutr. 11, 125-145. doi: 10.4067/S0718-95162011000300010

Akhtar, M. S., Siddiqui, Z. A., and Wiemken, A. (2011). Alternative Farming Systems, Biotechnology, Drought Stress and Ecological Fertilisation (Dordrecht: Springer) 263-292. doi: 10.1007/978-94-007-0 186-1_9

Akiyama, K., Matsuzaki, K. I., and Hayashi, H. (2005). Plant sesquiterpenes induce hyphal branching in arbuscular mycorrhizal fungi. Nature 435, 824-827. doi: $10.1038 /$ nature 03608

Al-Askar, A. A., and Rashad, Y. M. (2010). Arbuscular mycorrhizal fungi: a biocontrol agent against common bean Fusarium root rot disease. Plant Pathol. J. 9, 31-38. doi: 10.3923/ppj.2010.31.38

Alaux, P. L., Naveau, F., Declerck, S., and Cranenbrouck, S. (2020). Common mycorrhizal network induced JA/ET genes expression in healthy potato plants connected to potato plants infected by Phytophthora infestans. Front. Plant Sci. 11:602. doi: 10.3389/fpls.2020.00602

Ali, S., Duan, J., Charles, T. C., and Glick, B. R. (2014). A bioinformatics approach to the determination of genes involved in endophytic behavior in Burkholderia spp. J. Theor. Biol. 343, 193-198. doi: 10.1016/j.jtbi.2013. 10.007

Amini, R., Ebrahimi, A., and Dabbagh Mohammadi Nasab, A. (2020). Moldavian balm (Dracocephalum moldavica L.) essential oil content and composition as affected by sustainable weed management treatments. Ind. Crops Prod. 150:112416. doi: 10.1016/j.indcrop.2020.112416

Baylis, G. T. S. (1967). Experiments on the ecological significance of phycomycetous mycorrhizas. New Phytol. 66, 231-243. doi: 10.1111/j.1469-8137.1967.tb06001.x

\section{CONCLUSION}

Mycorrhizae-bacteria interactions, which occur mainly in rhizospheric soil, are of great relevance to stimulate plant growth, as well as for amelioration of plant abiotic and biotic stress. While a number of the reported studies are directly relevant to improving plant agriculture, deciphering the detailed molecular and ecological interactions between AM and PGPB is essential to developing a better understanding of the synergistic behavior between these groups of microorganisms.

\section{AUTHOR CONTRIBUTIONS}

GS, EG, and BG wrote the manuscript. All authors contributed to the article and approved the submitted version.

\section{FUNDING}

GS thanks Coordinación de la Investigación CientíficaUMSNH (2020-2021) and Consejo Nacional de Ciencia y Tecnología, México (Propuesta A1-S-15956) for supporting our research projects.

Behrooz, A., Vahdati, K., Rejali, F., Lotfi, M., Sarikhani, S., and Leslie, C. (2019). Arbuscular mycorrhiza and plant growth-promoting bacteria alleviate drought stress in walnut. HortScience 54, 1087-1092. doi: 10.21273/HORTSCI13961-19

Belimov, A. A., Shaposhnikov, A. I., Azarova, T. S., Makarova, N. M., Safronova, V. I., Litvinskiy, V. A., et al. (2020). Microbial consortium of PGPR, rhizobia and arbuscular mycorrhizal fungus makes pea mutant SGECdt comparable with indian mustard in cadmium tolerance and accumulation. Plants 9, 1-21. doi: 10.3390/plants9080975

Bender, S. F., Conen, F., and Van der Heijden, M. G. A. (2015). Mycorrhizal effects on nutrient cycling, nutrient leaching and $\mathrm{N}_{2} \mathrm{O}$ production in experimental grassland. Soil Biol. Biochem. 80, 283-292. doi: 10.1016/j.soilbio.2014.10.016

Berta, G., Copetta, A., Gamalero, E., Bona, E., Cesaro, P., Scarafoni, A., et al. (2014). Maize development and grain quality are differentially affected by mycorrhizal fungi and a growth-promoting pseudomonad in the field. Mycorrhiza 24, 161-170. doi: 10.1007/s00572-013-0523-x

Berta, G., Fusconi, A., and Hooker, J. E. (2002). Arbuscular mycorrhizal modifications to plant root systems: scale, mechanisms and consequences. Mycorrhizal Technol. Agric. 71-85. doi: 10.1007/978-3-0348-8117-3_6

Berta, G., Fusconi, A., and Trotta, A. (1993). VA mycorrhizal infection and the morphology and function of root systems. Environ. Exp. Bot. 33, 159-173. doi: 10.1016/0098-8472(93)90063-L

Bertaux, J., Schmid, M., Prevost-Boure, N. C., Churin, J. L., Hartmann, A., Garbaye, J., et al. (2003). In situ identification of intracellular bacteria related to Paenibacillus spp. in the mycelium of the ectomycorrhizal fungus Laccaria bicolor S238N. Appl. Environ. Microbiol. 69, 4243-4248. doi: 10.1128/AEM.69.7.4243-4248.2003

Bianciotto, V., Genre, A., Jargeat, P., Lumini, E., Becard, G., and Bonfante, P. (2004). Vertical transmission of endobacteria in the arbuscular mycorrhizal fungus Gigaspora margarita Through generation of vegetative spores. Appl Environ Microbiol. 70, 3600-3608.

Bianciotto, V., Lumini, E., Bonfante, P., and Vandamme, P. (2003). "Candidatus Glomeribacter gigasporarum" gen. nov., sp. nov., an endosymbiont of arbuscular mycorrhizal fungi. Int. J. Syst. Evol. Microbiol. 53, 121-124. doi: 10.1099/ijs.0.02382-0

Bona, E., Cantamessa, S., Massa, N., Manassero, P., Marsano, F., Copetta, A., et al. (2017). Arbuscular mycorrhizal fungi and plant growth-promoting pseudomonads improve yield, quality and nutritional value of tomato: a field study. Mycorrhiza 27, 1-11. doi: 10.1007/s00572-016-0727-y 
Bona, E., Todeschini, V., Cantamessa, S., Cesaro, P., Copetta, A., Lingua, G., et al. (2018). Combined bacterial and mycorrhizal inocula improve tomato quality at reduced fertilization. Sci. Hortic. 234, 160-165. doi: 10.1016/j.scienta.2018.02.026

Bonfante, P., and Anca, I. A. (2009). Plants, mycorrhizal fungi, and bacteria: a network of interactions. Annu. Rev. Microbiol. 63, 363-383. doi: 10.1146/annurev.micro.091208.073504

Bowles, T. M., Jackson, L. E., and Cavagnaro, T. R. (2018). Mycorrhizal fungi enhance plant nutrient acquisition and modulate nitrogen loss with variable water regimes. Glob. Chang. Biol. 24, e171-e182. doi: 10.1111/gcb.13884

Bowman, S. M., and Free, S. J. (2006). The structure and synthesis of the fungal cell wall. BioEssays 28, 799-808. doi: 10.1002/bies.20441

Brígido, C., Menéndez, E., Paço, A., Glick, B. R., Belo, A., Félix, M. R., et al. (2019). Mediterranean native leguminous plants: a reservoir of endophytic bacteria with potential to enhance chickpea growth under stress conditions. Microorganisms 7:392. doi: 10.3390/microorganisms7100392

Bryla, D. R., and Eissenstat, D. M. (2005). Respiratory costs of mycorrhizal associations. Plant Respiration, 207-224. doi: 10.1007/1-4020-3589-6_12

Bucher, M., Hause, B., Krajinski, F., and Küster, H. (2014). Through the doors of perception to function in arbuscular mycorrhizal symbioses. New Phytol. 204, 833-840. doi: 10.1111/nph.12862

Bücking, H., Mensah, J. A., and Fellbaum, C. R. (2016). Common mycorrhizal networks and their effect on the bargaining power of the fungal partner in the arbuscular mycorrhizal symbiosis. Commun. Integr. Biol. 9, 1-4. doi: 10.1080/19420889.2015.1107684

Cameron, D. D., Neal, A. L., van Wees, S. C., and Ton, J. (2013). Mycorrhizainduced resistance: more than the sum of its parts?. Trends Plant Sci. 18, 539-545. doi: 10.1016/j.tplants.2013.06.004

Cheng, Z., Park, E., and Glick, B. R. (2007). 1-Aminocyclopropane-1-carboxylate deaminase from Pseudomonas putida UW4 facilitates the growth of canola in the presence of salt. Can. J. Microbiol. 53, 912-918. doi: 10.1139/W07-050

Choudhary, D. K., and Johri, B. N. (2009). Interactions of Bacillus spp. and plants with special reference to induced systemic resistance (ISR). Microbiol. Res. 164, 493-513. doi: 10.1016/j.micres.2008.08.007

Churchland, C., and Grayston, S. J. (2014). Specificity of plant-microbe interactions in the tree mycorrhizosphere biome and consequences for soil $\mathrm{C}$ cycling. Front. Microbiol. 5:261. doi: 10.3389/fmicb.2014.00261

D’Amelio, R., Berta, G., Gamalero, E., Massa, N., Avidano, L., Cantamessa, S., et al. (2011). Increased plant tolerance against chrysanthemum yellows phytoplasma ('Candidatus Phytoplasma asteris') following double inoculation with Glomus mosseae BEG12 and Pseudomonas putida S1Pf1Rif. Plant Pathol. 60, 1014-1022. doi: 10.1111/j.1365-3059.2011.02479.x

Del Carmen Orozco-Mosqueda, M., Duan, J., DiBernardo, M., Zetter, E., CamposGarcía, J., Glick, B. R., et al. (2019). The production of ACC deaminase and trehalose by the plant growth promoting bacterium Pseudomonas sp. UW4 synergistically protect tomato plants against salt stress. Front. Microbiol. 10:1392. doi: 10.3389/fmicb.2019.01392

Dodds, P. N., Rafiqi, M., Gan, P. H. P., Hardham, A. R., Jones, D. A., and Ellis, J. G. (2009). Effectors of biotrophic fungi and oomycetes: pathogenicity factors and triggers of host resistance. New Phytol. 183, 993-1000. doi: 10.1111/j.1469-8137.2009.02922.x

Dowling, D. N., and O'Gara, F. (1994). Metabolites of Pseudomonas involved in the biocontrol of plant disease. Trends Biotechnol. 12, 133-141. doi: 10.1016/0167-7799(94)90091-4

Duan, J., Jiang, W., Cheng, Z., Heikkila, J. J., and Glick, B. R. (2013). The complete genome sequence of the plant growth-promoting bacterium Pseudomonas sp. UW4. PLoS ONE 8:e58640. doi: 10.1371/journal.pone.0058640

Dubois, M., Van den Broeck, L., and Inzé, D. (2018). The pivotal role of ethylene in plant growth. Trends Plant Sci. 23, 311-323. doi: 10.1016/j.tplants.2018.01.003

Duhamel, M., and Vandenkoornhuyse, P. (2013). Sustainable agriculture: possible trajectories from mutualistic symbiosis and plant neodomestication. Trends Plant Sci. 18, 597-600. doi: 10.1016/j.tplants.2013.08.010

Edwards, S. G., Young, J. P. W., and Fitter, A. H. (1998). Interactions between Pseudomonas fluorescens biocontrol agents and Glomus mosseae, an arbuscular mycorrhizal fungus, within the rhizosphere. FEMS Microbiol. Lett. 166, 297-303. doi: 10.1111/j.1574-6968.1998.tb13904.x

Emmanuel, O. C., and Babalola, O. O. (2020). Productivity and quality of horticultural crops through co-inoculation of arbuscular mycorrhizal fungi and plant growth promoting bacteria. Microbiol. Res. 239:126569. doi: 10.1016/j.micres.2020.126569
Etesami, H., and Beattie, G. A. (2017). "Plant-microbe interactions in adaptation of agricultural crops to abiotic stress conditions," in Probiotics and Plant Health (Singapore: Springer), 163-200. doi: 10.1007/978-981-10-3473-2_7

Etesami, H., and Glick, B. R. (2020). Halotolerant plant growth-promoting bacteria: prospects for alleviating salinity stress in plants. Environ. Exp. Bot. 178:104124. doi: 10.1016/j.envexpbot.2020.104124

Fadiji, A. E., and Babalola, O. O. (2020). Elucidating mechanisms of endophytes used in plant protection and other bioactivities with multifunctional prospects. Front. Bioeng. Biotechnol. 8:467. doi: 10.3389/fbioe.2020.00467

Forni, C., Duca, D., and Glick, B. R. (2017). Mechanisms of plant response to salt and drought stress and their alteration by rhizobacteria. Plant Soil 410, 335-356. doi: 10.1007/s11104-016-3007-x

Freire Cruz, A., and de Oliveira Soares, W. R. (2014). Impact of the arbuscular mycorrhizal fungi and bacteria on biocontrol of white root rot in fruit seedlings. J. Plant Physiol. Pathol. 02, 1-5. doi: 10.4172/2329-955X.1000114

Frey-Klett, P., Burlinson, P., Deveau, A., Barret, M., Tarkka, M., and Sarniguet, A. (2011). Bacterial-fungal interactions: hyphens between agricultural, clinical, environmental, and food microbiologists. Microbiol. Mol. Biol. Rev. 75, 583-609. doi: 10.1128/MMBR.00020-11

Frey-Klett, P., Garbaye, J., and Tarkka, M. (2007). The mycorrhiza helper bacteria revisited. New Phytol. 176, 22-36. doi: 10.1111/j.1469-8137.2007.02191.x

Gadkar, V., David-schwartz, R., Kunik, T., and Kapulnik, Y. (2001). Arbuscular mycorrhizal fungal colonization. Factors involved in host recognition. Plant Physiol. 127, 1493-1499. doi: 10.1104/pp.010783

Gahan, J., and Schmalenberger, A. (2014). The role of bacteria and mycorrhiza in plant sulfur supply. Front. Plant Sci. 5:723. doi: 10.3389/fpls.2014.00723

Gałazka, A., Grzadziel, J., Gałazka, R., Gawryjołek, K., Ukalska-Jaruga, A., and Smreczak, B. (2020). Fungal community, metabolic diversity, and glomalin-related soil proteins (GRSP) content in soil contaminated with crude oil after long-term natural bioremediation. Front. Microbiol. 11:572314. doi: 10.3389/fmicb.2020.572314

Gamalero, E., Berta, G., Massa, N., Glick, B. R., and Lingua, G. (2008) Synergistic interactions between the ACC deaminase-producing bacterium Pseudomonas putida UW4 and the AM fungus Gigaspora rosea positively affect cucumber plant growth. FEMS Microbiol. Ecol. 64, 459-467. doi: 10.1111/j.1574-6941.2008.00485.x

Gamalero, E., Berta, G., Massa, N., Glick, B. R., and Lingua, G. (2010). Interactions between Pseudomonas putida UW4 and Gigaspora rosea BEG9 and their consequences for the growth of cucumber under salt-stress conditions. J. Appl. Microbiol. 108, 236-245. doi: 10.1111/j.1365-2672.2009.04414.x

Gamalero, E., Bona, E., Todeschini, V., and Lingua, G. (2020). Saline and arid soils: impact on bacteria, plants, and their interaction. Biology 9, 1-27. doi: 10.3390/biology9060116

Gamalero, E., and Glick, B. R. (2020). The use of plant growth-promoting bacteria to prevent nematode damage to plants. Biology 9, 1-13. doi: 10.3390/biology9110381

Gamalero, E., Lingua, G., Berta, G., and Glick, B. R. (2009). Beneficial role of plant growth promoting bacteria and arbuscular mycorrhizal fungi on plant responses to heavy metal stress. Can. J. Microbiol. 55, 501-514. doi: 10.1139/W09-010

Gamalero, E., Trotta, A., Massa, N., Copetta, A., Martinotti, M. G., and Berta, G. (2004). Impact of two fluorescent pseudomonads and an arbuscular mycorrhizal fungus on tomato plant growth, root architecture and $\mathrm{P}$ acquisition. Mycorrhiza 14, 185-192. doi: 10.1007/s00572-003-0256-3

Garbaye, J. (1994). Tansley review No. 76 Helper bacteria: a new dimension to the mycorrhizal symbiosis. New Phytol. 128, 197-210. doi: 10.1111/j.1469-8137.1994.tb04003.x

Garbaye, J., and Bowen, G. D. (1989). Stimulation of ectomycorrhizal infection of Pinus radiata by some microorganisms associated with the mantle of ectomycorrhizas. New Phytol. 112, 383-388. doi: 10.1111/j.1469-8137.1989.tb00327.x

Garnett, T., Conn, V., and Kaiser, B. N. (2009). Root based approaches to improving nitrogen use efficiency in plants. Plant Cell Environ. 32, 1272-1283. doi: 10.1111/j.1365-3040.2009.02011.x

Genre, A., Lanfranco, L., Perotto, S., and Bonfante, P. (2020). Unique and common traits in mycorrhizal symbioses. Nat. Rev. Microbiol. 18, 649-660. doi: 10.1038/s41579-020-0402-3

Germida, J. J., and Walley, F. L. (1996). Plant growth-promoting rhizobacteria alter rooting patterns and arbuscular mycorrhizal fungi colonization of field-grown spring wheat. Biol. Fertil. Soils 23, 113-120. doi: 10.1007/BF00336050 
Ghanbarzadeh, Z., Mohsenzadeh, S., Rowshan, V., and Zarei, M. (2020). Mitigation of water deficit stress in Dracocephalum moldavica by symbiotic association with soil microorganisms. Sci. Hortic. 272:109549. doi: 10.1016/j.scienta.2020.109549

Gimenez, E., Salinas, M., and Manzano-Agugliaro, F. (2018). Worldwide research on plant defense against biotic stresses as improvement for sustainable agriculture. Sustain 10, 1-19. doi: 10.3390/su10020391

Glick, B. R. (2004). Bacterial ACC deaminase and the alleviation of plant stress. Adv. Appl. Microbiol. 56, 291-312. doi: 10.1016/S0065-2164(04)56009-4

Glick, B. R. (2012). Plant Growth-Promoting Bacteria: Mechanisms and Applications 2012. doi: 10.6064/2012/963401

Glick, B. R. (2020). Beneficial Plant-Bacterial Interactions, 2nd edition. Springer: Heidelberg. 383.

Govindarajulu, M., Pfeffer, P. E., Jin, H., Abubaker, J., Douds, D. D., Allen, J. W., et al. (2005). Nitrogen transfer in the arbuscular mycorrhizal symbiosis. Nature 435, 819-823. doi: 10.1038 /nature 03610

Graham, J. H. (2001). What do root pathogens see in mycorrhizas? New Phytol. 149, 357-359. doi: 10.1046/j.1469-8137.2001.00077.x

Guarino, C., Marziano, M., Tartaglia, M., Prigioniero, A., Postiglione, A., Scarano, P., et al. (2020). Poaceae with PGPR bacteria and arbuscular mycorrhizae partnerships as a model system for plant microbiome manipulation for phytoremediation of petroleum hydrocarbons contaminated agricultural soils. Agronomy 10, 1-17. doi: 10.3390/agronomy10040547

Hanin, M., Ebel, C., Ngom, M., Laplaze, L., and Masmoudi, K. (2016). New insights on plant salt tolerance mechanisms and their potential use for breeding. Front. Plant Sci. 7:1787. doi: 10.3389/fpls.2016.01787

Hardham, A. R. (2007). Cell biology of plant-oomycete interactions. Cell. Microbiol. 9, 31-39. doi: 10.1111/j.1462-5822.2006.00833.x

He, J. D., Chi, G. G., Zou, Y. N., Shu, B., Wu, Q. S., Srivastava, A. K., et al. (2020). Contribution of glomalin-related soil proteins to soil organic carbon in trifoliate orange. Appl. Soil Ecol. 154:103592. doi: 10.1016/j.apsoil.2020. 103592

Hernaández-Esquivel, A. A., Castro-Mercado, E., Valencia-Cantero, E., Alexandre, G., and García-Pineda, E. (2020). Application of Azospirillum brasilense lipopolysaccharides to promote early wheat plant growth and analysis of related biochemical responses. Front. Sustain. Food Syst. 4, 1-9. doi: $10.3389 /$ fsufs.2020.579976

Hernández-León, R., Rojas-Solís, D., Contreras-Pérez, M., OrozcoMosqueda, M. del C., Macías-Rodríguez, L. I., Reyes-de la Cruz, H., et al. (2015). Characterization of the antifungal and plant growthpromoting effects of diffusible and volatile organic compounds produced by Pseudomonas fluorescens strains. Biol. Control 81, 83-92. doi: 10.1016/j.biocontrol.2014.11.011

Hodge, A., and Storer, K. (2014). Arbuscular mycorrhiza and nitrogen: Implications for individual plants through to ecosystems. Plant Soil 386, 1-19. doi: 10.1007/s11104-014-2162-1

Hooker, J. E., Jaizme-Vega, M., and Atkinson, D. (1994). "Biocontrol of plant pathogens using arbuscular mycorrhizal fungi," in Impact of Arbuscular Mycorrhizas on Sustainable Agriculture and Natural Ecosystems, 191-200. doi: 10.1007/978-3-0348-8504-1_15

Horie, T., Karahara, I., and Katsuhara, M. (2012). Salinity tolerance mechanisms in glycophytes: an overview with the central focus on rice plants. Rice 5, 1-18. doi: 10.1186/1939-8433-5-11

$\mathrm{Hu}, \mathrm{Y}$., and Schmidhalter, U. (2005). Drought and salinity: a comparison of their effects on mineral nutrition of plants. J. Plant Nutr. Soil Sci. 168, 541-549. doi: $10.1002 / j p l n .200420516$

Iffis, B., St-Arnaud, M., and Hijri, M. (2014). Bacteria associated with arbuscular mycorrhizal fungi within roots of plants growing in a soil highly contaminated with aliphatic and aromatic petroleum hydrocarbons. FEMS Microbiol. Lett. 358, 44-54. doi: 10.1111/1574-6968.12533

Ilangumaran, G., and Smith, D. L. (2017). Plant growth promoting rhizobacteria in amelioration of salinity stress: a systems biology perspective. Front. Plant Sci. 8:1768. doi: $10.3389 /$ fpls.2017.01768

Imperiali, N., Chiriboga, X., Schlaeppi, K., Fesselet, M., Villacrés, D., Jaffuel, G., et al. (2017). Combined field inoculations of Pseudomonas bacteria, arbuscular mycorrhizal fungi, and entomopathogenic nematodes and their effects on wheat performance. Front. Plant Sci. 8:1809. doi: 10.3389/fpls.2017.01809
Inglis, G. D., and Kawchuk, L. M. (2002). Comparative degradation of oomycete, ascomycete, and basidiomycete cell walls by mycoparasitic and biocontrol fungi. Can. J. Microbiol. 48, 60-70. doi: 10.1139/w01-130

Jakobsen, I., Chen, B., Munkvold, L., Lundsgaard, T., and Zhu, Y. G. (2005). Contrasting phosphate acquisition of mycorrhizal fungi with that of root hairs using the root hairless barley mutant. Plant Cell Environ. 28, 928-938. doi: 10.1111/j.1365-3040.2005.01345.x

Johnson, N. C. (1993). Can fertilization of soil select less mutualistic mycorrhizae? Ecol. Appl. 3, 749-757. doi: 10.2307/1942106

Khatoon, Z., Huang, S., Rafique, M., Fakhar, A., Kamran, M. A., and Santoyo, G. (2020). Unlocking the potential of plant growth-promoting rhizobacteria on soil health and the sustainability of agricultural systems. J. Environ. Manage. 273:111118. doi: 10.1016/j.jenvman.2020.111118

Kim, H., Lee, M., Lee, J. H., Kim, K. H., Owens, G., and Kim, K. R. (2020). Distribution and extent of heavy metal(loid) contamination in agricultural soils as affected by industrial activity. Appl. Biol. Chem. 63:31. doi: 10.1186/s13765-020-00517-x

Kloepper, J. W., Leong, J., Teintze, M., and Schroth, M. N. (1980). Pseudomonas siderophores: a mechanism explaining disease-suppressive soils. Curr. Microbiol. 4, 317-320. doi: 10.1007/BF02602840

Krishnamoorthy, R., Kim, K., Subramanian, P., Senthilkumar, M., Anandham, R., and Sa, T. (2016). Arbuscular mycorrhizal fungi and associated bacteria isolated from salt-affected soil enhances the tolerance of maize to salinity in coastal reclamation soil. Agric. Ecosyst. Environ. 231, 233-239. doi: 10.1016/j.agee.2016.05.037

Kumar, A., Singh, S., Gaurav, A. K., Srivastava, S., and Verma, J. P. (2020). Plant growth-promoting bacteria: biological tools for the mitigation of salinity stress in plants. Front. Microbiol. 11:1216. doi: 10.3389/fmicb.2020.01216

Kuzyakov, Y., and Razavi, B. S. (2019). Rhizosphere size and shape: temporal dynamics and spatial stationarity. Soil Biol. Biochem. 135, 343-360. doi: 10.1016/j.soilbio.2019.05.011

Lee, Y., Krishnamoorthy, R., Selvakumar, G., Kim, K., and Sa, T. (2015). Alleviation of salt stress in maize plant by co-inoculation of arbuscular mycorrhizal fungi and Methylobacterium oryzae CBMB20. J. Korean Soc. Appl. Biol. Chem. 58, 533-540. doi: 10.1007/s13765-015-0072-4

Li, X., Rui, J., Mao, Y., Yannarell, A., and Mackie, R. (2014). Dynamics of the bacterial community structure in the rhizosphere of a maize cultivar. Soil Biol. Biochem. 68, 392-401. doi: 10.1016/j.soilbio.2013.10.017

Liu, H., Brettell, L. E., and Singh, B. (2020). Linking the phyllosphere microbiome to plant health. Trends Plant Sci. 25, 841-844. doi: 10.1016/j.tplants.2020.06.003

Liu, J. L., Xie, B. M., Shi, X. H., Ma, J. M., and Guo, C. H. (2015). Effects of two plant growth-promoting rhizobacteria containing 1-aminocyclopropane1-carboxylate deaminase on oat growth in petroleum-contaminated soil. Int. J. Environ. Sci. Technol. 12, 3887-3894. doi: 10.1007/s13762-015-0798-x

Lumini, E., Bianciotto, V., Jargeat, P., Novero, M., Salvioli, A., Faccio, A., et al. (2007). Presymbiotic growth and sporal morphology are affected in the arbuscular mycorrhizal fungus Gigaspora margarita cured of its endobacteria. Cell. Microbiol. 9, 1716-1729. doi: 10.1111/j.1462-5822.2007.0 0907.x

Ma, W., Guinel, F. C., and Glick, B. R. (2003). Rhizobium leguminosarum biovar viciae 1-aminocyclopropane-1-carboxylate deaminase promotes nodulation of pea plants. Appl. Environ. Microbiol. 69, 4396-4402. doi: 10.1128/AEM.69.8.4396-4402.2003

Maas, S., Scheifler, R., Benslama, M., Crini, N., Lucot, E., Brahmia, Z., et al. (2010). Spatial distribution of heavy metal concentrations in urban, suburban and agricultural soils in a Mediterranean city of Algeria. Environ. Pollut. 158, 2294-2301. doi: 10.1016/j.envpol.2010.02.001

MacDonald, R. M., Chandler, M. R., and Mosse, B. (1982). The occurrence of bacterium-like organelles in vesicular-arbuscular mycorrhizal fungi. New Phytol. 90, 659-663. doi: 10.1111/j.1469-8137.1982.tb03275.x

Madsen, E. L. (2011). Microorganisms and their roles in fundamental biogeochemical cycles. Curr. Opin. Biotechnol. 22, 456-464. doi: 10.1016/j.copbio.2011.01.008

Mahmood, S., Daur, I., Al-Solaimani, S. G., Ahmad, S., Madkour, M. H., Yasir, M., et al. (2016). Plant growth promoting rhizobacteria and silicon synergistically enhance salinity tolerance of mung bean. Front. Plant Sci. 7:876. doi: $10.3389 /$ fpls.2016.00876 
Marasco, R., Rolli, E., Ettoumi, B., Vigani, G., Mapelli, F., Borin, S., et al. (2012). A drought resistance-promoting microbiome is selected by root system under desert farming. PLoS ONE 7:e48479. doi: 10.1371/journal.pone.0048479

Massa, N., Cesaro, P., Todeschini, V., Capraro, J., Scarafoni, A., Cantamessa, S., et al. (2020). Selected autochthonous rhizobia, applied in combination with AM fungi, improve seed quality of common bean cultivated in reduced fertilization condition. Appl. Soil Ecol. 148:103507. doi: 10.1016/j.apsoil.2020.103507

Mayak, S., Tirosh, T., and Glick, B. R. (2004). Plant growth-promoting bacteria that confer resistance to water stress in tomatoes and peppers. Plant Sci. 166, 525-530. doi: 10.1016/j.plantsci.2003.10.025

Mercado-Blanco, J., Abrantes, I., Caracciolo, A. B., Bevivino, A., Ciancio, A., Grenni, P., et al. (2018). Belowground microbiota and the health of tree crops. Front. Microbiol. 9:1006. doi: 10.3389/fmicb.2018.01006

Meyer, J. R., and Linderman, R. G. (1986). Response of subterranean clover to dual inoculation with vesicular-arbuscular mycorrhizal fungi and a plant growthpromoting bacterium, Pseudomonas putida. Soil Biol. Biochem. 18, 185-190. doi: 10.1016/0038-0717(86)90025-8

Miransari, M. (2011). Interactions between arbuscular mycorrhizal fungi and soil bacteria. Appl. Microbiol. Biotechnol. 89, 917-930. doi: 10.1007/s00253-010-3004-6

Molina-Romero, D., Juárez-Sánchez, S., Venegas, B., Ortíz-González, C. S., Baez, A., Morales-García, Y. E., et al. (2021). A bacterial consortium interacts with different varieties of maize, promotes the plant growth, and reduces the application of chemical fertilizer under field conditions. Front. Sustain. Food Syst. 4:293. doi: 10.3389/fsufs.2020.616757

Morales-Cedeño, L. R., Orozco-Mosqueda, M. del C., Loeza-Lara, P. D., ParraCota, F. I., de los Santos-Villalobos, S., and Santoyo, G. (2021). Plant growth-promoting bacterial endophytes as biocontrol agents of pre- and postharvest diseases: fundamentals, methods of application and future perspectives. Microbiol. Res. 242:126612. doi: 10.1016/j.micres.2020.126612

Moreira, H., Pereira, S. I. A., Vega, A., Castro, P. M. L., and Marques, A. P. G. C. (2020). Synergistic effects of arbuscular mycorrhizal fungi and plant growth-promoting bacteria benefit maize growth under increasing soil salinity. J. Environ. Manage. 257:109982. doi: 10.1016/j.jenvman.2019.109982

Mortimer, P. E., Pérez-Fernández, M. A., and Valentine, A. J. (2008). The role of arbuscular mycorrhizal colonization in the carbon and nutrient economy of the tripartite symbiosis with nodulated Phaseolus vulgaris. Soil Biol. Biochem. 40, 1019-1027. doi: 10.1016/j.soilbio.2007.11.014

Mosse B (1970) Honey-coloured, sessile Endogone spores. II. Changes in fine structure during spore development. Arch Microbiol 74, 129-145

Mosse, B. (1973). Plant growth responses to vesicular-arbuscular mycorrhiza IV. In soil given additional phosphate. New Phytol. 72, 127-136. doi: 10.1111/j.1469-8137.1973.tb02017.x

Munné-Bosch, S., and Müller, M. (2013). Hormonal cross-talk in plant development and stress responses. Front. Plant Sci. 4:529. doi: 10.3389/fpls.2013.00529

Naito, M., Desirò, A., González, J. B., Tao, G., Morton, J. B., Bonfante, P., et al. (2017). 'Candidatus Moeniiplasma glomeromycotorum', an endobacterium of arbuscular mycorrhizal fungi. Int. J. Syst. Evol. Microbiol. 67, 1177-1184. doi: 10.1099/ijsem.0.001785

Naumann, M., Schüßler, A., and Bonfante, P. (2010). The obligate endobacteria of arbuscular mycorrhizal fungi are ancient heritable components related to the mollicutes. ISME J. 4, 862-871. doi: 10.1038/ismej.2010.21

Nepomuceno, R. A., Brown, C. M. B., Mojica, P. N., and Brown, M. B. (2019). Biological Control Potential of Vesicular Arbuscular Mycorrhizal Root Inoculant (VAMRI) and associated phosphate solubilizing bacteria, Pseudochrobactrum asaccharolyticum against soilborne phytopathogens of Onion (Allium cepa L. var. Red Creole). Arch. Phytopathol. Plant Prot. 52, 714-732. doi: 10.1080/03235408.2019.1644058

Offre, P., Pivato, B., Siblot, S., Gamalero, E., Corberand, T., Lemanceau, P., et al. (2007). Identification of bacterial groups preferentially associated with mycorrhizal roots of Medicago truncatula. Appl. Environ. Microbiol. 73, 913-921. doi: 10.1128/AEM.02042-06

Olanrewaju, O. S., Ayangbenro, A. S., Glick, B. R., and Babalola, O. O. (2019). Plant health: feedback effect of root exudates-rhizobiome interactions. Appl. Microbiol. Biotechnol. 103, 1155-1166. doi: 10.1007/s00253-018-9556-6

Orozco-Mosqueda, M. D. C., Glick, B. R., and Santoyo, G. (2020). ACC deaminase in plant growth-promoting bacteria (PGPB): an efficient mechanism to counter salt stress in crops. Microbiol. Res. 235:126439. doi: $10.1016 /$ j.micres.2020.126439
Orozco-Mosqueda, M. D. C., Rocha-Granados, M. D. C., Glick, B. R., and Santoyo, G. (2018). Microbiome engineering to improve biocontrol and plant growth-promoting mechanisms. Microbiol. Res. 208, 25-31. doi: 10.1016/j.micres.2018.01.005

Orozco-Mosqueda, M. del C., and Santoyo, G. (2021). Plant-microbial endophytes interactions: scrutinizing their beneficial mechanisms from genomic explorations. Curr. Plant Biol. 25:100189. doi: 10.1016/j.cpb.2020.100189

Paço, A., Da-Silva, J. R., Torres, D. P., Glick, B. R., and Brígido, C. (2020). Exogenous acc deaminase is key to improving the performance of pasture Legume-Rhizobial symbioses in the presence of a high manganese concentration. Plants 9, 1-23. doi: 10.3390/plants9121630

Palaniyandi, S. A., Damodharan, K., Yang, S. H., and Suh, J. W. (2014). Streptomyces sp. strain PGPA39 alleviates salt stress and promotes growth of 'Micro Tom'tomato plants. J. Appl. Microbiol. 117, 766-773. doi: $10.1111 /$ jam. 12563

Parihar, M., Meena, V. S., Mishra, P. K., Rakshit, A., Choudhary, M., Yadav, R. P., et al. (2019). Arbuscular mycorrhiza: a viable strategy for soil nutrient loss reduction. Arch. Microbiol. 201, 723-735. doi: 10.1007/s00203-019-01653-9

Peralta, H., Mora, Y., Salazar, E., Encarnación, S., Palacios, R., and Mora, J. (2004). Engineering the nifH promoter region and abolishing poly- $\beta$ hydroxybutyrate accumulation in Rhizobium etli enhance nitrogen fixation in symbiosis with Phaseolus vulgaris. Appl. Environ. Microbiol. 70, 3272-3281. doi: 10.1128/AEM.70.6.3272-3281.2004

Pereira, S. I. A., Monteiro, C., Vega, A. L., and Castro, P. M. L. (2016). Endophytic culturable bacteria colonizing Lavandula dentata L. plants: isolation, characterization and evaluation of their plant growth-promoting activities. Ecol. Eng. 87, 91-97. doi: 10.1016/j.ecoleng.2015.11.033

Phour, M., Sehrawat, A., Sindhu, S. S., and Glick, B. R. (2020). Interkingdom signaling in plant-rhizomicrobiome interactions for sustainable agriculture. Microbiol. Res. 241:126589. doi: 10.1016/j.micres.2020.126589

Porcel, R., Aroca, R., and Ruiz-Lozano, J. M. (2012). Salinity stress alleviation using arbuscular mycorrhizal fungi. A review. Agron. Sustain. Dev. 32, 181-200. doi: 10.1007/s13593-011-0029-x

Prosekov, A. Y., and Ivanova, S. A. (2018). Food security: the challenge of the present. Geoforum 91, 73-77. doi: 10.1016/j.geoforum.2018.02.030

Raklami, A., Bechtaoui, N., Tahiri, A. I., Anli, M., Meddich, A., and Oufdou, K. (2019). Use of rhizobacteria and mycorrhizae consortium in the open field as a strategy for improving crop nutrition, productivity and soil fertility. Front. Microbiol. 10:1106. doi: 10.3389/fmicb.2019.01106

Ravnskov, S., Cabral, C., and Larsen, J. (2020). Mycorrhiza induced tolerance in Cucumis sativus against root rot caused by Pythium ultimum depends on fungal species in the arbuscular mycorrhizal symbiosis. Biol. Control 141:104133. doi: 10.1016/j.biocontrol.2019.104133

Ravnskov, S., Larsen, J., and Jakobsen, I. (2002). Phosphorus uptake of an arbuscular mycorrhizal fungus is not effected by the biocontrol bacterium Burkholderia cepacia. Soil Biol. Biochem. 34, 1875-1881. doi: 10.1016/S0038-0717(02)00201-8

Requena, N., Jimenez, I., Toro, M., and Barea, J. M. (1997). Interactions between plant-growth-promoting rhizobacteria (PGPR), arbuscular mycorrhizal fungi and Rhizobium spp. in the rhizosphere of Anthyllis cytisoides, a model legume for revegetation in mediterranean semi-arid ecosystems. New Phytol. 136, 667-677. doi: 10.1046/j.1469-8137.1997.00786.x

Richardson, A. E., Barea, J. M., McNeill, A. M., and Prigent-Combaret, C. (2009). Acquisition of phosphorus and nitrogen in the rhizosphere and plant growth promotion by microorganisms. Plant Soil 321, 305-339. doi: 10.1007/s11104-009-9895-2

Rigamonte, T. A., Pylro, V. S., and Duarte, G. F. (2010). The role of Mycorrhization helper bacteria in the establishment and action of ectomycorrhizae associations. Brazilian J. Microbiol. 41, 832-840. doi: 10.1590/S1517-838220100004 00002

Rodríguez-Flores, J. M., Medellín-Azuara, J., Valdivia-Alcalá, R., Arana-Coronado, O. A., and García-Sánchez, R. C. (2019). Insights from a calibrated optimization model for irrigated agriculture under drought in an irrigation district on the central Mexican high plains. Water 11, 1-23. doi: 10.3390/w110 40858

Ruiz-Lozano, J. M., and Bonfante, P. (1999). Identification of a putative P-transporter operon in the genome of a Burkholderia strain living inside the arbuscular mycorrhizal fungus Gigaspora margarita. J. Bacteriol. 181, 4106-4109. doi: 10.1128/JB.181.13.4106-410 9.1999 
Ruiz-Lozano, J. M., and Bonfante, P. (2000). A Burkholderia strain living inside the arbuscular mycorrhizal fungus Gigaspora margarita possesses the vacB gene, which is involved in host cell colonization by bacteria. Microb. Ecol. 39, 137-144. doi: 10.1007/s002480000008

Salcedo Gastelum, L. A., Díaz Rodríguez, A. M., Félix Pablos, C. M., Parra Cota, F. I., Santoyo, G., Puente, M. L., et al. (2020). The current and future role of microbial culture collections in world food security. Front. Sustain. Food Syst. 4:291. doi: 10.3389/fsufs.2020.614739

Salido, A. L., Hasty, K. L., Lim, J. M., and Butcher, D. J. (2003). Phytoremediation of arsenic and lead in contaminated soil using Chinese brake ferns (Pteris vittata) and Indian mustard (Brassica juncea). Int. J. Phytoremed. 5, 89-103. doi: $10.1080 / 713610173$

Santoyo, G., Guzmán-Guzmán, P., Parra-Cota, F. I., Santos-Villalobos, S., de los Orozco-Mosqueda, M. del C., and Glick, B. R. (2021). Plant growth stimulation by microbial consortia. Agron 11:219. doi: 10.3390/agronomy11020219

Santoyo, G., Hernández-Pacheco, C., Hernández-Salmerón, J., and HernándezLeón, R. (2017). The role of abiotic factors modulating the plant-microbe-soil interactions: toward sustainable agriculture. A review. Spanish J. Agric. Res. 15:13. doi: $10.5424 /$ sjar/2017151-9990

Santoyo, G., Moreno-Hagelsieb, G., del Carmen Orozco-Mosqueda, M., and Glick, B. R. (2016). Plant growth-promoting bacterial endophytes. Microbiol. Res. 183, 92-99. doi: 10.1016/j.micres.2015.11.008

Sarma, B. K., Yadav, S. K., Singh, S., and Singh, H. B. (2015). Microbial consortiummediated plant defense against phytopathogens: readdressing for enhancing efficacy. Soil Biol. Biochem. 87, 25-33. doi: 10.1016/j.soilbio.2015.04.001

Savary, S., Willocquet, L., Pethybridge, S. J., Esker, P., McRoberts, N., and Nelson, A. (2019). The global burden of pathogens and pests on major food crops. Nat. Ecol. Evol. 3, 430-439. doi: 10.1038/s41559-018-0793-y

Sharma, I. P., and Sharma, A. K. (2017). Physiological and biochemical changes in tomato cultivar PT-3 with dual inoculation of mycorrhiza and PGPR against root-knot nematode. Symbiosis 71, 175-183. doi: 10.1007/s13199-016-0423-x

Sharma, P., and Dubey, R. S. (2005). Drought induces oxidative stress and enhances the activities of antioxidant enzymes in growing rice seedlings. Plant Growth Regul. 46, 209-221. doi: 10.1007/s10725-005-0002-2

Shaul, O., Galili, S., Volpin, H., Ginzberg, I., Elad, Y., Chet, I., et al. (1999). Mycorrhiza-induced changes in disease severity and PR protein expression in tobacco leaves. Mol. Plant-Microbe Interact. 12, 1000-1007. doi: 10.1094/MPMI.1999.12.11.1000

Sikes, B. A. (2010). When do arbuscular mycorrhizal fungi protect plant roots from pathogens? Plant Signal. Behav. 5, 763-765. doi: 10.4161/psb.5.6.11776

Singh, D. P., Singh, H. B., and Prabha, R. (2016). Microbial Inoculants in Sustainable Agricultural Productivity: Vol. 1: Research Perspectives (New Delhi: Springer) 1-343. doi: 10.1007/978-81-322-2647-5

Singh, R., Soni, S. K., and Kalra, A. (2013). Synergy between Glomus fasciculatum and a beneficial Pseudomonas in reducing root diseases and improving yield and forskolin content in Coleus forskohlii Briq. under organic field conditions. Mycorrhiza 23, 35-44. doi: 10.1007/s00572-012-0447-x

Song, Y., Chen, D., Lu, K., Sun, Z., and Zeng, R. (2015). Enhanced tomato disease resistance primed by arbuscular mycorrhizal fungus. Front. Plant Sci. 6:786. doi: 10.3389/fpls.2015.00786

Spatafora, J. W., Chang, Y., Benny, G. L., Lazarus, K., Smith, M. E., Berbee, M. L., et al. (2016). A phylum-level phylogenetic classification of zygomycete fungi based on genome-scale data. Mycologia 108, 1028-1046. doi: 10.3852/ 16-042

Splivallo, R., Deveau, A., Valdez, N., Kirchhoff, N., Frey-Klett, P., and Karlovsky, P. (2015). Bacteria associated with truffle-fruiting bodies contribute to truffle aroma. Environ. Microbiol. 17, 2647-2660. doi: 10.1111/1462-2920.12521

Svenningsen, N. B., Watts-Williams, S. J., Joner, E. J., Battini, F., Efthymiou, A., Cruz-Paredes, C., et al. (2018). Suppression of the activity of arbuscular mycorrhizal fungi by the soil microbiota. ISME J. 12, 1296-1307. doi: 10.1038/s41396-018-0059-3

Ton, J., Flors, V., and Mauch-Mani, B. (2009). The multifaceted role of ABA in disease resistance. Trends Plant Sci. 14, 310-317. doi: 10.1016/j.tplants.2009.03.006

Torres de los Santos, R., Molinero Rosales, N., Ocampo, J. A., and GarcíaGarrido, J. M. (2016). Ethylene alleviates the suppressive effect of phosphate on arbuscular mycorrhiza formation. J. Plant Growth Regul. 35, 611-617. doi: $10.1007 / \mathrm{s} 00344-015-9570-1$
Trivedi, P., Leach, J. E., Tringe, S. G., Sa, T., and Singh, B. K. (2020). Plantmicrobiome interactions: from community assembly to plant health. Nat. Rev. Microbiol. 18, 607-621. doi: 10.1038/s41579-020-0412-1

Turan, M., and Esringü, A. (2007). Phytoremediation based on canola (Brassica napus L.) and Indian mustard (Brassica juncea L.) planted on spiked soil by aliquot amount of $\mathrm{Cd}, \mathrm{Cu}, \mathrm{Pb}$, and $\mathrm{Zn}$. Plant Soil Environ. 53, 7-15. doi: 10.17221/3188-PSE

Ullah, A., Nisar, M., Ali, H., Hazrat, A., Hayat, K., Keerio, A. A., et al. (2019). Drought tolerance improvement in plants: an endophytic bacterial approach Appl. Microbiol. Biotechnol. 103, 7385-7397. doi: 10.1007/s00253-019-10045-4

Van der Ent, S., Van Wees, S. C. M., and Pieterse, C. M. J. (2009). Jasmonate signaling in plant interactions with resistance-inducing beneficial microbes. Phytochemistry 70, 1581-1588. doi: 10.1016/j.phytochem.2009.06.009

Van Der Heijden, M. G. A. (2010). Mycorrhizal fungi reduce nutrient loss from model grassland ecosystems. Ecology 91, 1163-1171. doi: 10.1890/09-0336.1

Van Geel, M., De Beenhouwer, M., Ceulemans, T., Caes, K., Ceustermans, A., Bylemans, D., et al. (2016). Application of slow-release phosphorus fertilizers increases arbuscular mycorrhizal fungal diversity in the roots of apple trees. Plant Soil 402, 291-301. doi: 10.1007/s11104-015-2777-x

Vigo, C., Norman, J. R., and Hooker, J. E. (2000). Biocontrol of the pathogen Phytophthora parasitica by arbuscular mycorrhizal fungi is a consequence of effects on infection loci. Plant Pathol. 49, 509-514. doi: 10.1046/j.1365-3059.2000.00473.x

Vivas, A., Azcón, R., Biró, B., Barea, J. M., and Ruiz-Lozano, J. M. (2003). Influence of bacterial strains isolated from lead-polluted soil and their interactions with arbuscular mycorrhizae on the growth of Trifolium pratense L. under lead toxicity. Can. J. Microbiol. 49, 577-588. doi: 10.1139/w03-073

Vives-Peris, V., de Ollas, C., Gómez-Cadenas, A., and Pérez-Clemente, R. M. (2020). Root exudates: from plant to rhizosphere and beyond. Plant Cell Rep. 39, 3-17. doi: 10.1007/s00299-019-02447-5

Vlček, V., and Pohanka, M. (2020). Glomalin - an interesting protein part of the soil organic matter. Soil Water Res. 15, 67-74. doi: 10.17221/29/2019-SWR

Vos, M., Wolf, A. B., Jennings, S. J., and Kowalchuk, G. A. (2013). Micro-scale determinants of bacterial diversity in soil. FEMS Microbiol. Rev. 37, 936-954. doi: 10.1111/1574-6976.12023

Wang, Z., Mei, X., Du, M., Chen, K., Jiang, M., Wang, K., et al. (2020). Potential modes of action of Pseudomonas fluorescens ZX during biocontrol of blue mold decay on postharvest citrus. J. Sci. Food Agric. 100, 744-754. doi: $10.1002 /$ jsfa. 10079

Wehner, J., Antunes, P. M., Powell, J. R., Mazukatow, J., and Rillig, M. C. (2010). Plant pathogen protection by arbuscular mycorrhizas: a role for fungal diversity? Pedobiologia 53, 197-201. doi: 10.1016/j.pedobi.2009.10.002

Whipps, J. M. (2004). Prospects and limitations for mycorrhizas in biocontrol of root pathogens. Can. J. Bot. 82, 1198-1227. doi: 10.1139/b04-082

Wu, Y., Ma, L., Liu, Q., Vestergård, M., Topalovic, O., Wang, Q., et al. (2020). The plant-growth promoting bacteria promote cadmium uptake by inducing a hormonal crosstalk and lateral root formation in a hyperaccumulator plant Sedum alfredii. J. Hazard. Mater. 395:122661. doi: 10.1016/j.jhazmat.2020.122661

Xing, R., Yan, H. Y., Gao, Q. B., Zhang, F. Q., Wang, J. L., and Chen, S. L. (2018). Microbial communities inhabiting the fairy ring of Floccularia luteovirens and isolation of potential mycorrhiza helper bacteria. J. Basic Microbiol. 58, 554-563. doi: 10.1002/jobm.201700579

Zsögön, A., Lambais, M. R., Benedito, V. A., Figueira, A. V. D. O., and Peres, L. E. P. (2008). Reduced arbuscular mycorrhizal colonization in tomato ethylene mutants. Sci. Agric. 65, 259-267. doi: 10.1590/S0103-90162008000300006

Conflict of Interest: The authors declare that the research was conducted in the absence of any commercial or financial relationships that could be construed as a potential conflict of interest.

Copyright (๑) 2021 Santoyo, Gamalero and Glick. This is an open-access article distributed under the terms of the Creative Commons Attribution License (CC BY). The use, distribution or reproduction in other forums is permitted, provided the original author(s) and the copyright owner(s) are credited and that the original publication in this journal is cited, in accordance with accepted academic practice. No use, distribution or reproduction is permitted which does not comply with these terms. 